\title{
34th Congress of the European Society for Surgical Research (ESSR)
}

\section{Abstracts}

34th Congress

Bern, Switzerland

April 22-24, 1999
Editors

M.W. Büchler, Bern

H.U. Baer, Bern 
S. Karger

Medical and Scientific Publishers

Basel $\cdot$ Freiburg $\cdot$ Paris $\cdot$ London

New York $\cdot$ New Delhi $\cdot$ Bangkok

Singapore $\cdot$ Tokyo $\cdot$ Sydney
Drug Dosage

The authors and the publisher have exerted every effort to ensure that drug selection and dosage set forth in this text are in accord with current recommendations and practice at the time of publication. However, in view of ongoing research, changes in government regulations, and the constant flow of information relating to drug therapy and drug reactions, the reader is urged to check the package insert for each drug for any change in indications and dosage and for added warning and precautions. This is particularly important when the recommended agent is a new and/or infrequently employed drug.
All rights reserved

No part of this publication may be translated into other languages, reproduced or utilized in any form or by any means, electronic or mechanical, including photocopying, recording, microcopying, or by any information storage and retrieval system, without permission in writing from the publisher or, in the case of photocopying, direct payment of a specified fee to the Copyright Clearance Center (see 'General Information').

(c) Copyright 1999 by S. Karger AG,

P.O. Box, CH-4009 Basel (Switzerland)

Printed in Switzerland on acid-free paper by

Reinhardt Druck, Basel

ISBN 3-8055-6892-4

\section{KARGER}

Fax+4161306 1234

E-Mail karger@karger.ch

www.karger.com 


\section{European \\ Surgical Research}

Oral Presentations

Walter Brendel Session

11 Induction of Osteoporosis in Sheep: A Pilot Study

Schneider, E.; Lill, C.A.; Flügel, A.K. (Davos, Switzerland)

12 Chronic Lack of Extrinsic Neural Input Increases Nitric Oxide (NO) Independent Inhibition After Rat Small Bowel Transplantation (SBT) Balsiger, B.M.; Ohtani, N.; Anding, W.J.; Duenes, J.A.; Sarr, M.G. (Rochester, Minnesota, USA)

23 Portal Venous Injection-Induced Tolerance Gets over MHC Barriers Morita, H.; Nakamura, N.; Sakakura, Y.; Wei, T.; Satoi, S.; Yoshida, K.; Oda, M.; Inoue, T.; Inui, H.; Nagahama, T.; Kamiyama, Y.; Ikehara, S. (Osaka, Japan)

24 Activation of Apoptosis by Agonistic Anti-CD95 Antibodies Induces Hepatic Microvascular Perfusion Failure and Decreases Kupffer Cell Clearance Capacity

Mica, L.; Wanner, G.A.; Trentz, O.; Ertel, W. (Zurich, Switzerland)

35 Tumor Suppressor Gene p53 and Oncogenes in Ulcerative Colitis-Associated and Sporadic Colorectal Carcinoma Brüwer, M.; Schmid, K.W.; Winde, G.; Senninger, N.; Schürmann, G. (Münster, Germany)

36 Towards Antiangiogenic Therapy for Cancer: Continuous Administration of Human Angiostatin in Mice

Drixler, T.A.; Ritchie, E.D.; Aarsman, C.J.; Reyerkerk, A.; Voest, E.E; Gebbink, M.F.; Borel Rinkes, I.H. (Utrecht, The Netherlands)
47 Microencapsulated Human Parathyroid Xenografts: Long Term In Vivo Function Without Systemic Immunosuppression

Hasse, C.; Bohrer, T.; Zielke, A.; Zimmermann, U.; Rothmund, M. (Würzburg, Germany)

58 The Impact of Elevated Intraabdominal Pressure During Laparoscopy on Intraperitoneal Tumor Growth in a Rat Model Ordemann, J.; Jacobi, C.A.; Müller, J.M. (Berlin, Germany)

Gastrointestinal Surgery I

59 A Novel Preoperative Lymph Node Staging of Superficial Esophageal Cancer Using Positron Emission Tomography

Kirihara, Y.; Kobori, O.; Kosaka, N.; Hara, T. (Tokyo, Japan)

610 MIB-1 Proliferation Rate - A Predictor for Response of Preoperative Radio-Chemotherapy in Esophageal Cancer?

Jenkner, J.; Reinshagen, K.; Ihling, C.; Ruf, G.; Imdahl, A. (Freiburg, Germany)

611 Utility of 99mTc-MIBI for Neoadjuvant Chemotherapy Against Gastric Cancer

Kawada, K.; Iwata, S.; Takabayashi, A. (Osaka, Japan)

$7 \quad 12$ Results of Polish Multicenter Gastric Cancer Study; A Special Reference to Tumor- and Tumor-Related Prognostic Factors Popiela, T.; Kulig, J. (Kraków, Poland)

\section{KARGER \\ (ㄷ) 1999 S. Karger AG, Basel}

Fax +41 613061234

E-Mail karger@karger.ch

www.karger.com
http://BioMedNet.com/karger
Accessible online at: 
$7 \quad 13$ Neuro-Endocrine Type of Gastric Carcinoma

Chen Bi-fen, Yin, H. (Fuzhou, P.R.China)

714 Prognostic Significances of dThdPase Expression in Gastric Carcinoma

Ogawa, K.; Konno, S.; Katsube, T.; Hosokawa, T.; Naritaka, Y.; Kajiwara, T. (Tokyo, Japan)

815 Roux-en-Y Gastric Bypass (RYGB) as Primary Operation for Morbid Obesity at the Mayo Clinic

Balsiger, B.M.; Sarr, M.G. (Rochester, Minnesota, USA)

816 Nadroparin Calcium vs Heparin Sodium in Prevention of Thromboembolism in Surgical Patients

Egger, B.; Schmid, S.; Naef, M.; Wildi, S.; Büchler, M.W. (Bern, Switzerland)

Vascular and Cardiac Surgery I

917 Delayed Venous Repair Heightens Local Skeletal Muscle and Remote Lung Injury in Combined Lower Limb Arterial and Venous Trauma Harkin, D.W.; Barros D'Sa, A.A.B.; Yassin, M.M.I.; Young, C.V.; Halliday, M.I. (Belfast, Northern Ireland)

1018 A High-Resolution Esophageal ECG for Detecting Intraoperative Myocardial Ischemia During Coronary Artery Bypass Surgery

Huber, St.; Mächler, H.; Lueger, A.; Berger, J.; Anelli-Monti, M.; Stark, G.; Rehak, P.; Rigler, B. (Graz, Austria)

1019 Morphology of Transmyocardial Laser Revascularisation

Mueller, X.M.; Tevaearai, H.T.; Genton, C.Y.; Von Segesser, L.K. (Lausanne, Switzerland)
1120 TMLR has no Beneficial Effect on High energy Phosphates and Lactate During Acute Myocardial Ischemia in Pigs

Reuthebuch, O.; Podzuweit, Th.; Thomas, S.; Binz, K.; Roth, M.; Klövekorn, W.P.; Bauer, E.P. (Bad Nauheim, Germany)

1121 Transabdominal Computer Enhanced Endoscopic Coronary Bypass Surgery

Autschbach, R.; Falk, V.; Walther, T.; Moll, F.; Diegeler, A.; Mohr, F.W. (Leipzig, Germany)

1222 Slow-Thawing After Arterial Cryopreservation Improves the Integrity and Viability of the Vascular Endothelium

Contreras, L.A.; G ${ }^{a}$ Honduvilla, N.; Pascual, G.; Gimeno, M.J.; Buján, J.; Bellón, J.M. (Madrid, Spain)

1323 Performance of an Acellular, Composite Porcine Heart Valve Bioprosthesis in the Ovine RVOT Goldstein, S.; Walsh, S.; Black, K.; Orton, E.C.; Clarke, D. (Denver, Colo., USA)

Minimally Invasive Surgery I

1324 Laparoscopic Imaging of the Biliary Tract and Bile Leaks using the Fluorescent Bile Acid Cholylglycylamidofluorescein (CGF): A New Method for Prevention and Detection of Biliary Tract Injury during Laparoscopy

Holzinger, F.; Krähenbühl, L.; Schteingart, C.D.; Ton-Nu, H.-T.; Baer, H.U.; Hofmann, A.F.; Büchler, M.W. (San Diego, Calif., USA, Bern, Switzerland)

1425 Influence of $\mathrm{CO}_{2}$ Pneumoperitoneum in Lactate Metabolism During Laparoscopic Cholecystectomy: Intraoperative and Postoperative Study

Ortiz-Oshiro, E.; García, J.C.A.; Mayol, J.; Juan, M.A.S.; Fdez-Represa, J.A. (Madrid, Spain) 
1526 Lockable Universal Joint for Handle-Shaft Articulation of Endoscopic Instruments

Emam, T.A.; Hofer, M.; Frank, T.G.;

Stockham, G.; Cuschieri, A. (Dundee, Scotland)

1527 Down-Regulated Secretion of Th1-Type and Pro-Inflammatory Cytokines by T-Cells Following Conventional, but not Laparoscopic Surgery

Wilke, W.; Brune, I.B.; Hensler, Th.;

Holzmann, B.; Siewert, J.-R. (München, Germany)

1628 Quantitative Analysis of Laparoscopic Surgery

den Boer, K.T.; Dankelman, J.; de Wit, L.T.; Gouma, D.J.; Stassen, H.G.; (Delft/Amsterdam, The Netherlands)

1629 The Influence of a

Pneumoperitoneum on the Subperitoneal Implantation of Intraperitoneal Free Spleen Cell Suspension in an Experimental Animal Model

Gamal, E.M.; Furka, I.; Nagy, P.; Irén, M.; Kiss, J. (Debrecen, Hungary)

1730 Cardiovascular Changes During Laparoscopic Cholecystectomy: Is Patient Selection a Must?

Helmy, A.; Marwan, I.; Hammad, E.; Wahba, A.; El-Metwally, G. (Menoufia, Egypt)

1831 Error Analysis of Technical Complications During Laparoscopic Fundoplications

Gantert, W.A.; von Flüe, M.; Wildisen, A.; Patti, M.G.; Way, L.W. (Luzern, Switzerland; San Franciso, USA)
Organ and Tissue Transplantation IV and Orthopedics and Traumatology I

1832 Analysis of Microcirculatory Perfusion Quality for Kidney and Liver Procurement from Non-Heart-Beating Donors: Comparison Between HTK and UW Solution

Yamauchi, J.; Richter, S.; Minor, T.; Vollmar, B.; Menger, M.D. (Homburg/Saar and Bonn, Germany)

1933 The Effect of Acute Rejection Upon Expression of Fibrosis Associated Genes in Renal Transplant Recipients White, S.A.; Bicknell, G.R.; Jain, S.; Williams, S.T.; Doughman, T.; Knight, A.; Furness, P.; Nicholson, M.L. (Leicestershire, United Kingdom)

2034 Immunomodulation by Photoinactivation of T-Cell Clones in Experimental Pancreatic Islet Transplantation

Roveda, L.; Trotta, F.; Valsecchi, P.; Viarengo, G.L.; Perotti, C.; Salvaneschi, L.; Prati, U. (Pavia, Italia)

2035 Development of Hypothermic Continuous Perfusion Preservation Machine Equipped with Non-Pulsatile Pump and Its Clinical Application

Kozaki, K.; Sakurai, E.; Uchiyama, M.; Matsuno, N.; Kozaki, M.; Nagao, T. (Tokyo, Japan)

2136 Immigration of Macrophages into the Fracture of Rat Tibiae Secured by Stable or Unstable Intramedullary Pins

Probst, A.; Hankemeier, S.; Palmes, D.; Plenz, G.; Spiegel, H.-U. (Münster, Germany)

2137 Morote-Nailing: A Minimal-Invasive Method for Treatment of Unstable Forearm Fractures in Children

Ambacher, T.; Erli, H.J.; Paar, O. (Aachen, Germany)

Eur Surg Res Vol. 31, Suppl. 1, 1999 
2238 The Effect of Bonematrix Gelatine (BMG) on Fresh Osteochondral Allografts. An In Vivo Study in a Dog Model

Bakay, A.; Bráth, E.; Csönge, L.; Mikó, I.; Furka, I. (Budapest and Györ, Hungary)

Vascular and Cardiac Surgery II

2339 Transrenal Fixation of Endoprotheses

Marty, B.; von Segesser, L.K.; Müller, X.; Angeburger, M. (Lausanne, Switzerland)

2340 Influence of the Ultrasound Contrast Agent Levovist on Human Nailfold Capillary Microscopy Immer, F.F.; Seiler, A.M.; Aeschbacher, B.C.; Mahler, F.; Saner, H. (Bern, Switzerland)

2441 A Novel Tissue Bioadhesive (BioGlue $^{\circledR}$ ) for Thoracic Aorta Repair in Coagulopathic Sheep

Hewitt, C.W.; Marra, S.; Chrzanowski, A.N.F.J.; Tatem, L.D.; Cilley, J.H.; DelRossi, A.J. (Camden, NJ, USA)

$24 \quad 42$ Titanium Clips vs Sutures in Venous Anastomoses

Dimakakos, P.B.; Kotsis, T.E.; Doufas, A.G.; Pafiti, A. (Athens, Greece)

2543 Nonsurgical Reconstruction of Thoracic Aortic Dissection

Wolf, W.; Király, Zs.; Nienaber, Chr. (Hamburg, Germany)

2544 Predictors for Successful Mini-Maze-Operation

Szalay, Z.A.; Skwara, W.; Pitschner, H.F.; Klövekorn, W.-P.; Bauer, E.P. (Bad Nauheim, Germany)

2645 Prognostic Value of Troponin-I in Paediatric Cardiac Surgery

Immer, F.F.; Seiler, A.M.; Pfammatter, J.P.; Stocker, F.; Carrel, T. (Bern, Switzerland)
Minimally Invasive Surgery II

2646 Laparoscopy in the Treatment of Mid and Low Rectal Cancer

Diaz-E, J.A.; Franklin, M.E.; Abrego, D.; Balli, J.; Glass, J.L. (San Antonio, Texas, USA)

2747 Laparoscopic Colon Resection for Cancer

Franklin, M.E.; Diaz-E, J.A.; Abrego, D.; Balli, J.; Glass, J.L. (San Antonio, Texas, USA)

2748 Quality of Life Outcome after Laparoscopic Gastric Banding Weiner, R.; Datz, H.; Blanco-Engert, R.; Bockhorn, H. (Frankfurt, Germany)

2749 Microlaparotomy versus Laparoscopic Cholecystectomy, as Assessed by their Metabolic Responses Gál, I.; Lantos, J.; Röth, E.; Szalai, H.; Hejjel, L. (Gyöngyös-Pécs, Hungary)

2850 Rocker Handle for Endoscopic Needle Drivers: Technical and Ergonomic Evaluation

Emam, T.A.; Frank, T.G.; Hanna, G.B.; Stockham, G.; Cuschieri, A. (Dundee, Scotland)

2851 Laparoscopic Distal Pancreatic Resection with the Preservation of the Spleen

Tihanyi, T.F.; Nehéz, L.; Horváth, L.; Winternitz, T. (Budapest, Hungary)

2952 Minimally Invasive Surgery Advanced Training Course: Our Experience along Six Years

Ortiz-Oshiro, E.; Mayol, J.; De la Torre, J.; Calderón, T.; De Diego, J.A.; Fdez-Represa, J.A. (Madrid, Spain)

Organ and Tissue Transplantation II

3053 Different Effects of Sandimmun and Neoral on Migration of Lymph Cells to Allograft and Lymphoid Tissue

Maksymowicz, M.; Olszewski, W.L.; Zaleska, M. (Warsaw, Poland) 
3054 Heart Preservation of Non-Heart-Beating Donors by In-Situ-Perfusion: Comparison of the Artificial Oxygen Carrier Perfluorocarbon with UW-Solution in a Big Animal Model

Scheule, A.M.; Pappas, J.; Strotmann, C.; Vogel, U.; Miller, S.; Reuter, S.; Wendel, H.P.; Ziemer, G. (Tübingen, Germany)

3155 Pulmonary Graft Function after Long-Term Hypothermic Preservation of NHBD-Lungs

Löhe, F.; Müller, C.; Bittmann, I.; Messmer, K.; Schildberg, F.W. (Munich, Germany)

3256 Immunoadsorption Prevents Hyperacute Rejection of Xenogeneic Perfused Working Hearts

Brenner, P.; Hinz, M.; Huber, H.; Schmoeckel, M.; Reichenspurner, H.; Hammer, C.; Reichart, B. (Munich, Germany)

3257 Opioids Influence Lymphocyte Circulation and Homing

Maksymowicz, M.; Kosson, D.; Lipkowski, A.W.; Olszewski, W.L. (Warsaw, Poland)

3358 Cyclosporin A Combination Therapy Prolongs Composite Tissue Allograft Survival in a Swine Model Zdichavsky, M.; Ustuner, T.; Jones, J.W.; Edelstein, J.; Breidenbach, W.; Jevans, A. Maldonado, C.; Barker, J.H. (Louisville, Ky., USA)

3359 Scoring of Skin Rejection for Monitoring Composite Tissue Allograft (CTA) Rejection in a Swine Model

Zdichavsky, M.; Ray, M.; Jones, J.W.; Ustuner, T.; Edelstein, J.; Breidenbach, W.; Maldonado, C.; Barker, J.H. (Louisville, Ky., USA)

3460 Bone Cryopreservation: Sustained Proliferation Potency by DMSO

Egli, R.J.; Sckell, A.; Fraitzl, C.R.; Hofstetter, W.; Felix, R.; Ganz, R.; Leunig, M. (Bern,

Switzerland)
Orthopedics and Traumatology II

35 61 Spread of Infection after External Fixator Pin Tract Infection

Clasper, J.C.; Simpson, A.H.R.W.; Watkins, P.E. (Oxford, England)

3562 Effect of Controlled Transduction of Tensile Forces on the Biomechanical Properties of Healing Tendons in a Microsurgical Model in Mice

Palmes, D.; Spiegel, H.U.; Freise, H.; Langer, M.; Probst, A. (Münster, Germany)

$36 \quad 63$ Gait and Stair Ambulation in Individuals after Total Knee Joint Replacement

Kramers-de Quervain, I.; Munzinger, U.; Stüssi, E. (Zürich, Switzerland)

3764 Extracorporeal Shock Waves Induce Periosteal Bone Formation in the Rabbit

Maier, M.; Milz, S.; Tischer, T.; Refior, H.J.; Delius, M. (Munich, Germany)

$37 \quad 65$ Improved Intramedullary Nail Interlocking in Osteoporotic Bone Ito, K.; Hungerbühler, R.; Wahl, D.; Grass, R. (Davos, Switzerland)

3866 Enhancement of Callus Formation during Limb Lengthening by Pulsed Ultrasound

Pommer, A.; Hahn, M.; Muhr, G. (Bochum, Germany)

3967 Evaluation of S-100b in Serum as a Specific Marker of Neuronal Damage

Mussack, T.; Biberthaler, P.; Wiedemann, E.; Englert, A.; Gippner-Steppert, C.; Jochum, M. (Munich, Germany)

Gastrointestinal Surgery II

3968 Enhanced Tumour Take in Naive Recipients after Passive Transfer of Surgery Related Factors

Aalbers, A.G.J.; van Rossen, M.E.E.; van den Tol, M.P.; Marquet, R.L.; Jeekel, J.; van

Eijck, C.H.J. (Rotterdam, The Netherlands) 
4069 MMP and TIMP Expression in Colorectal Cancer

Leaper, D.J.; Baker E.A.; Bergin, F.G. (Cleveland, United Kingdom)

4070 Treatment of Liver Metastases with Radio-Labelled Octreotide

Aalbers, A.G.J.; Slooter, G.D.; Breeman, W.A.P.; Krenning, E.P.; Marquet, R.L.; van Eijck, C.H.J. (Rotterdam, The Netherlands)

4171 Extramesenteric Lymphatic Flow along Pelvic Autonomic Nerves in Rectal Cancer

Maeda, K.; Maruta, M.; Utsumi, T. (Aichi, Toyoake, Japan)

4172 Extramesenteric Micrometastases in Rectal Cancer

Maeda, K.; Maruta, M.; Utsumi, T. (Aichi, Toyoake, Japan)

4273 Neoangiogenesis in Human Colorectal Cancer Is Dependent on Different Stages of Disease and Proliferation

Bruenagel, G.; Walgenbach, K.J.; Fischer, H.P.; Hirner, A.; Minor, T. (Bonn, Germany)

4274 Blocking of Integrin Function Leads to Less Tumour Cell Adhesion In Vivo and In Vitro

van Rossen, M.E.E.; Aalbers, A.G.J.;

Marquet, R.L.; Jeekel, J.; van Eijck, C.H.J.

(Rotterdam, The Netherlands)

4375 Diagnosis and Therapy Monitoring of Rectal Carcinoma by Positron Emission Tomography using C-11-Methionine

Ott, K.; Weber, W.; Nekarda, H.; Matzen, K.; Zimmermann, F.; Schwaiger, M.; Fink, U.; Siewert, J.R. (Munich, Germany)
Shock, Microcirculation and Reperfusion Injury I

4476 Dynamic Distribution of Microcirculatory Blood Flow in the Gastrointestinal Tract during Haemorrhagic Shock

Krejei, V.; Erni, D.; Banie, A.; Sigurdsson, G.H. (Bern, Switzerland)

4477 Hypoxia-Induced Reductive Stress and Methane Production in the Dog Boros, M.; Ghyczy, M.; Wolfárd, A. (Köln, Germany; Szeged, Hungary)

4578 IL-2 Increases the Percentage of $\mathrm{CD4}^{+} \mathrm{CD8}^{+}$IEL after Ischemia/Reperfusion Injury

Nüssler, N.C.; O'Brien, J.; Stange, B.; K.-Platz, P.; Neuhaus, P.; Mueller, A.R. (Berlin, Germany)

4679 Preconditioning of the Heart: Second Window of Protection (SWOP) in Pigs

Jaberansari, M.T.; Muller, C.A.; Baxter, G.F.; Latouf, S.; McCarthy, J.; Rõth, E.; Yellon, D.M. Opie, L.H. (Cape Town, South Africa; London, United Kingdom; Pécs, Hungary)

4680 Anti-Oxidant Vitamins Prevent Neutrophil Mediated Remote Lung Injury in Combined Lower Limb Arterial and Venous Trauma Harkin, D.W.; Barros D'Sa, A.A.B.; Yassin, M.M.I.; Young, I.S.; McCaigue, M.D.; Halliday, M.I. (Belfast, N.Ireland)

4781 ACE-Inhibition in the Treatment of Hepatic Ischemia/Reperfusion Injury Freise, H.; Palmes, D.; Spiegel, H.U. (Münster, Germany)

4782 Effects of L-Arginine and Glycine on Hepatic Microcirculation and Cellular Integrity During Warm Ischemia/Reperfusion in Pigs

Schindl, M.; Solimann, T.; Längle, F.; Grünberger, T.; Sabbas, A.; Waldmann, E.; Steininger, R.; Roth, E.; Mühlbacher, F. (Vienna, Austria) 
$48 \quad 83$ The Effect of Metabolic Acidosis and Alkalosis on Subcutaneous Tissue Gases and $\mathbf{p H}$

Mellström, Å.; Jedlinska, B.; Hartmann, M.;

Jönsson, K. (Malmö, Sweden)

Organ and Tissue Transplantation I

4984 Combined Application of Heparin and Phentolamine, but not Heparin alone, reduces Microvascular Injury in Liver Preservation of Non-Heart-Beating Donors

Richter, S.; Yamauchi, J.; Minor, T.; Menger, M.D.; Vollmar, B. (Bonn, Germany)

4985 Kupfer Cell Depletion Attenuates Microcirculatory Failure After Liver Transplantation in Rats

Schauer, R.; Kalmuk, S.; Rüttinger, D.; Schildberg, F.W.; Messmer, K. (Munich, Germany)

5086 The Functional Evaluation of Xenoperfused Pig Livers

Uesugi, T.; Ikai, I.; Satoh, S.; Kanazawa, A.; Takeyama, O.; Nishitai, R.; Katsura, N.; Okabe, H.; Yamaoka, Y. (Kyoto, Japan)

5087 Different Impact of Warm Ischemia Periods and Perfusion Pressures on Preservation of Liver Microvasculature of Non-Heart-Beating Donors Richter, S.; Yamauchi, J.; Minor, T.; Menger, M.D.; Vollmar, B. (Bonn, Germany)

5188 Effect of Warm Preflush with Streptokinase on Microcirculatory Perfusion of UW Solution in Rat Kidneys from Non-Heart-Beating Donors

Yamauchi, J.; Richter, S.; Vollmar, B.; Menger, M.D.; Minor, T. (Bonn, Germany)

5289 Auxiliary Liver Transplantation with Portal Vein Arterialization as a Therapeutic Concept in Acute Liver Failure in the Rat

Schleimer, K.; Lange, R.; Rauen, U.; Beckurts, K.T.E.; Erhard, J.; Hölscher, A.H. (Cologne, Germany)
5290 Comparison of HTK, UW and Celsior in a Hepatocyte Suspension Preservation Model

Abrahamse, S.L.; Hartman, R.J.; van Gulik, T.M. (Amsterdam, The Netherlands)

5391 Arterial Reconstruction in Liver and Pancreas Allograft Transplantation Following Multiorgan Procurement

Hesse, U.J.; Troisi, R.; de Hemptinne, B.;

Pattyn, P.; Lameire, N. (Gent, Belgium)

Molecular Biology I

5492 Tamoxifen is Anti-Angiogenic In Vitro and Attenuates VEGF-Mediated Angiogenesis In Vivo Without Adverse Effects on Wound Healing

McNamara, D.A.; Harmey, J.; Wang, J.H.; Donovan, D.; Kay, E.; Walsh, T.N.; Bouchier-Hayes, D.J. (Dublin, Ireland) (Invited, no Abstract available)

5493 Enhanced Interleukin 10 Production in Colorectal Cancer Predicts the Development of Metastases

Chin, K.F.; Topping, K.; O'Hara, R.; Gaskell, K.; Greenman, J.; Hartley, J.; MacDonald, A.; Kerin, M.J.; Monson, J.R.T. (Hull, United Kingdom)

5494 Immunohistochemical Expression of Metallothionein in Inflammatory Bowel Disease

Brüwer, M.; Schmid, K.W.; Winde, G.; Senninger, N.; Schürmann, G. (Münster, Germany)

5595 Reduced Lung Injury after Kupffer Cell Blockade in Acute Pancreatitis in Mice and Rats Gloor, B.; Mueller, C.A.; Mai, G.; Tcholakov, O.; Uhl, W.; Reber, H.A.; Büchler, M.W. (Bern, Switzerland) 
5596 The Presence of Phospholipase A2 Type II Improves the Prognosis in Pancreatic Cancer

Berberat, P.; Friess, H.; Uhl, W.; Kashiwagi, M.; Zimmermann, A.; Büchler, M.W. (Bern, Switzerland)

5697 Transgenic Expression of HGF/SF Enhanced Survival of Transplanted Hepatocytes in Spleen

Sakata, H.; Takayama, H.; LaRochelle, W.J.; Merlino, G.; Onodera, K.; Kato, K.; Kasai, S.; Mito, M.; Rubin, J.S. (Asahikawa, Japan)

5698 Interleukin-10 Secretion from Human Malignant Tumors and its Inhibition by AS 101

Teitz, S.; Kalechman, Y.; Sredni, B.; Halevy, A. (Zerifin, Israel)

5799 Serum Vascular Endothelial Growth Factor Can Select Patients for Adjuvant Treatment following Curative Surgery for Colorectal Cancer

Chin, K.F.; Kumar, H.; Topping, K.; O'Hara, R.; Greenman, J.; Hartley, J.; MacDonald, A.; Kerin, M.J.; Monson, J.R.T. (Hull, United Kingdom)

Shock, Microcirculation and Reperfusion Injury II

58100 State of the Art in Cardiovascular Flow Measurements

Walpoth, B. (Bern, Switzerland) (Invited, no Abstract available)

58101 Effects of Tacrolimus/MMF on Swine Small Bowel Perfusion after Ischemia-Reperfusion

Braun, F.; Schütz, E.; Christians, U.;

Shipkova, M.; Hosseini, M.; Laabs, S.; Bothur, P.; Elias, K.; Ringe, B. (San Francisco, USA; Göttingen, Germany)

59102 Less Turbulences in Optimally Orientated Medtronic Hall Versus St-Jude Medical Aortic Valves Perthel, M.; Kleine, P.; Nygaard, H.; Hansen, S.; Paulsen, P.; Riis, C.; Laas, J. (Bad Bevensen, Germany, and Aarhus, Denmark)
59103 Mucosal Blood Flow and Growth Factors in Gastric Ulceration

Thomson, S.R.; Clarke, D.L. (Durban, South Africa)

59104 Microvascular Ischemia-Reperfusion Injury in Freshly Transplanted Bone

Sckell, A.; Demhartner, T.J.; Fraitzl, C.R.; Leunig, M. (Bern, Switzerland)

60105 Energy-Rich-Phosphates in Post-Ischemic Skeletal Muscle are Improved by Ischemic Preconditioning Mattei, A.; Sutter, P.-M.; Marx, A.; Harder, F.; Heberer, M.; Gürke, L. (Basel, Switzerland)

Gene Therapy I and Molecular Biology II

61106 Stable Transfection of Glypican-1 Antisense mRNA Decreases-Tumorigenicity of PANC-1 Pancreatic Cancer Cells

Kleeff, J.; Wildi, S.; Friess, H.; Büchler, M.W.; Korc, M. (Bern, Switzerland)

61107 In Vitro and In Vivo Transduction of Endothelial Cells with AAV Vectors

Stangl, M.; Theodorou, D.; Krapp, J.; Schulze, C.; Wildhirt, S.; Reichenspurner, H.; Hacker, U.; Doenicke, A.; Hallek, M. (Munich, Germany)

62108 Gene Therapy of hIL-10 and hIL-13 Abolishes LPS Tolerance in Non-Lethal Endotoxemia

Rogy, M.A.; Beinhauer, B.G.; Baumhofer, J.; Sturlan, S. (Vienna, Austria)

62109 Vaccination Against Liver Metastases of Colon Cancer by Suicide Gene Therapy in Rat Baqué, P.; Pierrefite, V.; Benchimol, D.; Bernard, J.L.; Bourgeon, A. (Nice, France)

63110 Apoptosis Inhibitor $\mathrm{Bcl}-\mathrm{xL}$ is Activated in Pancreatic Cancer and Deteriorates the Prognosis

Martignoni, M.E.; Friess, H.; Zhao Lu, CKulli, h.; Berberat, P.; Graber, H.; Zimmermann, A.; Büchler, M.W. (Bern, Switzerland) 
63111 p53 and CD34 in Carcinogenesis of Colorectal Cancer

Spisni, R.; Faviana, P.; Castagna, M.; Biondi, R.; Baroncini, R.; Pingitore, R.; Colizzi, C.; Dolfi, A.

Lagomarsini, B. (Pisa, Italy)

Hepatobiliary and Pancreatic Surgery I

64112 Radiofrequency Ablation of Malignant Liver Tumors:

Development of a New RF System and Treatment Algorithm in the Animal Model

Gantert, W.A.; von Flüe, M.; Wildisen, A.;

Patti, M.G.; Way, L.W. (San Francisco, USA)

64113 Experimental Studies of Electrolytic Ablation for Treating Patients with Unresectable Liver Metastases

Wemyss-Holden, S.A.; Robertson, G.S.M ; Maddern, G.J.; Dennison, A.R. (Leicester, United Kingdom)

65114 Electrochemical Ablation of Colorectal Liver Metastases - First Reported Use in Patients

Wemyss-Holden, S.A.; Maddern, G.J.; Dennison, A.R. (Leicester, United Kingdom)

65115 Suppression of TNF $\alpha$ Production in the Liver After Heat Shock Preconditioning

Yonezawa, K.; Yamamoto, Y.; Yamamoto, H.; Kume, M.; Yamagami, K.; Ishikawa, Y.; Uchinami, H.; Shimahara, Y.; Yamaoka, Y. (Kyoto, Japan)

66116 Influence of Octreotid on Intrahepatic Metastasis and Lipidperoxidation in BOP-Induced Pancreatic Cancer in Syrian Hamster Wenger, F.A.; Kilian, M.; Jacobi, C.A.; Schimke, I.; Müller, J.M. (Berlin, Germany)

66117 Assessment of Plasma Hyaluronic Acid in Anhepatic Pigs Treated with a Bioartificial Liver

Abrahamse, S.L.; Sosef, M.N.; van Runnard Heimel, P. ; Chamuleau, R.A.F.M; van

Gulik, T.M. (Amsterdam, Netherlands)
67118 Cytoreductive Hepatectomy Combined with Percutaneous Isolated Hepatic Perfusion for Local Control of Advanced Hepatocellular Carcinoma Ku, Y.; Tsuchida, S.; Takamatsu, M.; Kusunoki, N.; Fukumoto, T.; Iwasaki, T.; Tominaga, M.; Kuroda, Y. (Kobe, Japan)

68119 Portal Triad Clamping Versus no Inflow-Clamping for Partial

Hepatectomy for Hepatocellular Carcinoma

Tsuchida, S.; Ku, Y.; Kuroda, Y. (Kobe, Japan)

Tissue Repair and Wound Healing I

68120 Impairment of Wound Healing by Starch Glove-Powder is Dose-Dependent

Appleton, S.G.; Davis, P.A.; Wastell, C.; Thompson, J.N.; Allen-Mersh, T.G. (London, United Kingdom)

69121 Guided Tissue Regeneration: A Novel Approach to Fistula Management

Kirkpatrick, J.; Kim, D.; Alam, H.; Fitzgerald, T.; Nguyen, W.; Provido, H. (Washington, DC, USA)

69122 Upregulation of Tumor Suppressor Protein Neurofibromin in Normal Human Wound Healing and In Vitro Evidence for Platelet Derived Growth Factor (PDGF) and Transforming Growth Factor-beta1 (TGF-beta1) Elicited Increase in Neurofibromin mRNA Steady-State Levels in Dermal Fibroblasts

Laato, M.; Yla-Outinen, H.; Aaltonen, V.; Hirvonen, O.; Niinikoski, J.; Peltonen, J. (Oulu, Finland)

70123 Longterm Methylprednisolone Medication Improves the Healing of Small Bowel Anastomosis in Rats

Kujala, J.; Inkinen, K.; Smeds, C.-G.; Ahonen, J. (Helsinki, Finland) 
70124 Evaluation of Human Autologous Fibrin Sealant in the Prevention of Air Leaks Following Lung Resection in the Pig

Pedersen, J.H.; Krasnik, M.; Weis-Fogh, U.; Kjaergard, H.; Fleron, H. (Copenhagen, Denmark)

71125 Instillation-Vacuum-Sealing (IVS) in Treatment of Infected Mesh-Graft in Hernia Surgery

Butters, M.; Russ, M. (Bietigheim-Bissingen, Germany)

71126 Histological and Biomechanical Behaviour of PTFE and Poly-Propylene in the Presence of Infection

Contreras, L.A.; G ${ }^{a}$-Carranza, A.; Jurado, F.; Carrera Buján, A.; Bellón, J.M. (Madrid, Spain)

72127 Active Warming during Operative Surgery Reduces Postoperative Pressure Ulcers

Leaper, D.J.; Scott, E.M.; Bergin, F.G. (Cleveland, United Kingdom)

Shock, Microcirculation and Reperfusion Injury III

72128 Influence of Age on the Sensitivity of Isolated and Perfused Rat Livers Exposed to Oxidative Stress

Nardo, B.; Catena, F.; Turi, P.; Santoni, B.; Cavallari, G.; De Notariis, S.; Gasbarrini, A.; Pasini, P.; Roda, A.; Cavallari, A. (Bologna, Italy)

73129 Effect of 21-Aminosteroid on IkB Proteins and Cytokine Production in Lipopolysaccharide-Stimulated Kupffer Cells

Okada, K.; Marubayashi, S.; Fukuma, K.; Hinoi, T.; Ikeda, M.; Maeda, T.; Oshiro, Y.; Dohi, K. (Hiroshima, Japan)

74130 Pentoxifylline Resuscitation in a Porcine Model of SIRS

Parker, S.J.; Brown, D.; Kenward, C.E.; and Watkins, P.E. (Salisbury, England)
74131 Delayed Ischaemic Preconditioning and the Role of Oxygen Free Radicals

Jaberansari, M.T.; Jorgensen, J.J.; Borsiczky, B.; Rõth, E. (Pécs, Hungary)

75132 Effect of Fasting on Mitochondrial Injury in a Rat Model of Fatty Liver

Nardo, B.; Caraceni, P.; Grattagliano, I.;

Catena, F.; Santoni, B.; Turi, P.; Cavallari, G.; Domenicali, M.; Dall'Agata, M.;

Vendemiale, G.L.; Altomare, E.; Bernardi, M.; Cavallari, A. (Bologna, Italy)

75133 Pharmacological Evidence for Vasoprotective Action of Allopurinol During Ischemia/Reperfusion on Renal Arteries in Animal Experiments. Preliminary Results Mikó, I.; Schmidt, E.; Szentmiklósi, A.J.; Csabina, S.; Oláh, A.; Incze, D.; Hauck, M.; Kovács, J.; Petö, K.; Furka, I. (Debrecen, Hungary)

Hepatobiliary and Pancreatic Surgery II

76134 Cytokinin But Not Tachykinin Gene Expression is Increased in Chronic Pancreatitis

Di Sebastiano, P.; Di Febbo, C.; Mola, F.; Baccante, G.; Pernthaler, H.; Innocenti, P.; Friess, H.; Büchler, M.W. (Bozen/Chieti, Italy; Bern, Switzerland)

77135 A Reliable Model of Chronic Pancreatitis in the Pig

Boerma, D.; Straatsburg, I.H.; van Noorden, C.J.F.; Gouma, D.J.; van Gulik, T.M. (Amsterdam, The Netherlands)

77136 Experimental In Vivo Glucose Monitoring with a Subcutaneously Implanted Microdialysis System Berns, T.; Vering, T.; Adam, S.; Behrens, R.; Schäfer, R.; Steinkuhl, R.; Leder, S.; Tombach, B.; Weiss, T.; Knoll, M. (Münster, Germany)

78137 Autologous Islet Transplantation to Prevent Diabetes After Pancreas Resection for Chronic Pancreatitis White, S.A.; Davies, J.E.; Pollard, C.; Sutton, C.D.; Berry, D.P.; London, N.J.; Dennison, A.R. (Leicester, United Kingdom) 
78138 Fusidine and the Cytokine Response in an Experimental Model of Acute Pancreatitis

Osman, M.O.; El-Sefi, T.; Lausten, S.B.; Jacobsen, N.O.; Larsen, C.G.; Jensen, S.L. (Aarhus, Denmark, Alexandria, Egypt)

79139 Regional Intra-Arterial Application of Somatostatin in Acute Necrotizing Pancreatitis

Zlatarski, G.; Grigorov, G.; Lulchev, D.; Staikov, P.; Rusev, D.; Christov, V. (Sofia, Bulgaria)

79140 Role of Arachidonic Acid Metabolism and its Inhibition by Hydrocortisone in Experimental Acute Pancreatitis

Tcholakov, O.; Uhl, W.; Gloor, B.;

Bischofberger, H.; Müller, Ch.; Büchler, M.W. (Sofia, Bulgaria; Bern, Swizerland)

80141 Effects of Sodium Nitroprusside, Superoxide Dismutase, and Heparin on Acute Liver Injury and the Associated Mucosal Changes and Bacterial Translocation

Adawi, D.; Kasravi, F.B.; Mao, Y.; Molin, G.; Jeppsson, B. (Malmö, Sweden)

Organ and Tissue Transplantation III

81142 Celsior $^{\circledR}$ or Perfadex ${ }^{\circledR}$ for Prolonged Lung Preservation. Which Solution is Superior?

Brandes, H.; Albes, J.; Conzelmann, A.; Kalinka, A.; Ziemer, G. (Tübingen, Germany)

81143 Lymphocyte Sensitivities to Cyclosporine in Their Clinical Significance on Renal Transplantation Kozaki, K.; Takeuchi, H.; Hirano, T.; Kozaki, M.; Nagao, T. (Tokyo, Japan)

82144 Orthotopic Heart Transplantation in the Pig: Predictors for Survival Walpoth, B.H.; Nicolaus, B.; Celic, B.; Walpoth, N.; Krejici, V.; Hiltebrand, L.; Sigurdsson, G.; Carrel, T.; Althaus, U. (Bern, Switzerland)
82145 Comparison of Major Immunocompatibility Difference between Inbred Pig Strains for Transplantation Studies

Tam, P.K.H.; Chan, J.K.Y.; Dallman, M.J. (Hongkong, China; London, United Kingdom)

83146 Technique of Immunoadsorption in Orthotopic Xenotransplantation of Pig Hearts in Baboons

Brenner, P.; Reichenspurner, H.; Schmoeckel, M.; Wimmer, C.; Rucker, A.; Eder, V.; Hinz, M.; Felbinger, T.; Müller-Höcker, J.; Seidel, D.; Hammer, C.; Reichart, B. (Munich, Germany)

84147 The Impact of Prolonged Cold Ischemia on Delayed Graft Function (DGF) in Experimental Porcine Pancreas Transplantation

Troisi, R.; Meester, D.; Regaert, B.; Broucke, C.V.; Hesse, U.J. (Gent, Belgium)

84148 Porcine Living Liver Transplantation Using a Vascular Prosthesis to Replace the Intrahepatic Vena Cava

Nardo, B.; Catena, F.; Santoni, B.; Turi, P.; De Vincentis, F.; Simoncini, M.; Faenza, A.; Bellusci, R.; Cavallari, A. (Bologna, Italy)

Abdominal Sepsis I and Minimally Invasive Surgery III

85149 Inhibiting Tissue NF- $\kappa$ B and NF-IL6 Activation Improves Survival in Abdominal Sepsis

Browder, W.; Ha, T.; Li, C.; Kalbfleisch, J.; Laffan, J.; Williams, D. (Johnson City, Tenn. USA)

85150 Evaluation of the Different Translocated Bacterial Types and Microflora in an Acute Liver Injury Model and Lactobacillus plantarum Administration

Adawi, D.; Wang, M.; Ahrné, S.; Molin, G.; Jeppsson, B. (Malmö, Sweden) 
86151 Peritoneal IL-6 and MCP-1 Production as a Response to Surgical Trauma

Haupt, W.; Riese, J.; Denzel, C.; Hohenberger, W. (Erlangen, Germany)

86152 Lymph from Inflammatory Tissues Gives Insight into the Local Molecular Processes not Reflected in Serum

Olszewski, W.L.; Galkowska, H.; Ziolkowska, A.; Zaleska, M. (Warsaw, Poland)

$87 \quad 153$ The Role of IL-12 and IL-18 in Murine Intraabdominal Infection

Maier, S.; Entleutner, M.; Zantl, N.;

Emmanuilidis, K.; Pfeffer, K.; Heidecke, C.-D. (Munich, Germany)

87154 Prevention of Port Site Metastasis Almeida, J.A.; Franklin, M.E.; Diaz-E, J.A.; Abrego, D.; Glass, J.L. (San Antonio, Texas, USA)

88155 Laparoscopic Treatment of Incisional and Abdominal Wall Hernia with a New Personal Technique.

Report of the First 100 Cases

Carbajo, M.A.; Garcia-Caballero, M.; Martin, J.I.; Blanco, J.I.; Delacuesta, M.; Martin, F.;

Toledano, M. (Málaga, Spain)

88156 Effect of Experience on Task Performance and Motion Pattern of Surgeons

Emam, T.A.; Hanna, G.B.; Kimber, C.;

Cuschieri, A. (Dundee, Scotland)

Gastrointestinal Surgery III

89157 Low Preoperative Serum Albumin Independently Predicts Poor Survival in Patients with Colorectal Cancer Sutton, C.D.; White, S.A.; Ubhi, S.; Imeson, J.; Veitch, P.S. (Leicester, United Kingdom)

89158 Defecation Properties after Low Anterior Resection and Straight Colo-Anal Anastomosis - An Experimental Study in Pigs Debus, E.S.; Sailer, M.A.; Fuchs, K.H.; Thiede, A. (Würzburg, Germany)
90159 Surgical Defunctioning Enhances Intestinal Permeability and Mortality after Colon Anastomosis in the Rat

Månsson,P.; Fork, T.; Jeppsson, B.; Thorlacius, H. (Malmö, Sweden)

90160 A New Look at Endoanal Ultrasonography

Kaur, G.; Gardiner, A.; Duthie, G.S. (Hull, United Kingdom)

91161 Oral versus Parenteral Nutrition after Colorectal Surgery: A Prospective Randomized Trial

Autikainen, T.; Kostamoinen, L.; Simpura, E.-M.; Kairaluoma, M.; Mecklin, J.-P. (Jyväskylä, Finland)

91162 Effect of Enteral Glutamine on Nutritive-Metabolic Changes and Plasmatic Amino Acid Levels after Malabsorptive Surgery

García-Caballero, M.; Muñoz, M.; Pérez-Miranda, E.; Martinez-Moreno, J.M.; Rius, F.; Villagrasa, E.; Toval, J.A.; García-Ceballos, A. (Málaga, Spain)

92163 Inflammatory Cytokines Predict Clinical Outcomes After Elective Colorectal Surgery

Leaper, D.J.; Bergin, F.G.; Baker, E.A.; Mallinder, P.A.; Royle, P. (Cleveland, United Kingdom)

92164 Oral Antibiotic Prophylaxis in Major Colorectal Surgery - A Pilot Study

Stupnicki, A.F.; Breitenmoser, I.; Frey, C.; Büchler, M.W. (Berne, Switzerland)

Molecular Biology III

93165 Realization of a Surgical Cancer Model in Transgenic Animals

Fein, M.; Fuchs, K.-H.; Peters, J.H.; Shibata, D.; Laird, P.W.; Skinner, K.A. (Würzburg, Germany) 
93166 Connective Tissue Growth Factor (CTGF) Regulates Fibrogenesis in Chronic Pancreatitis

di Mola, F.F.; Friess, H.; Martignoni, M.E.; Di Sebastiano, P.; Zimmermann, A.; Innocenti, P.; Graber, H.; Gold, L.I.; Korc, M.; Büchler, M.W. (Bern, Switzerland)

94167 Glutathione and TGF $\alpha$ in the Cell Cycle of the Pancreatic Adenocarcinoma Cell Line AsPC-1 Schnelldorfer, T.; Gansauge, S.; Gansauge, F.; Leder, G.; Beger, H.G.; Nüssler, A.K. (Ulm, Germany)

94168 Is the Differential Expression of Growth Factor Receptors in Papilla of Vater and Pancreatic Cancer a Cause for Different Prognosis?

Martignoni, M.E.; Wang, L.; Zu, Z.; Gerber, R.; Schröder, M.; Fukuda, A.; Zimmermann, A.; Korc, M.; Büchler, M.W. (Bern, Switzerland)

95169 Divergent Expression of the Helix-Loop-Helix (HLH) Proteins Id-1, Id-2, and Id-3 in Pancreatic Cancer and Chronic Pancreatitis Kleeff, J.; Maruyama, H.; Friess, H.; Büchler, M.W.; Kore, M. (Irvine, Calif., USA; Bern, Switzerland)

96170 Effects of Neurotensin-(NT) on Human Colonic Mucosa In Vitro Riegler, M.; Castagliuolo, I.; Mun, E.C.; Wlk, M.; Sogukoglu, T.; Bischof, G.; Cosentini, E.; Teleky, B.; Matthews, J.B.; Pothoulakis, C.; Wenzl, E. (Boston, Mass., USA)

96171 Vitamin D Receptor Genotypes in Patients with Primary and Secondary Hyperparathyroidism Kaun, M.; Frilling, A.; Broelsch, C.E. (Essen, Germany)

97172 Regeneration of Larynx Cartilage by Osteogenic Protein-1

Majstorovic, L.; Katic, V.; Shi, M.-S.; Maticic, D.; Yin, S.; McCartney, J.; Vukicevic, S. (Zagreb, Croatia)
Hepatobiliary and Pancreatic Surgery III

97173 DNA-Image-Cytometry in the Surrounding Tissue of HCC

Riesener, K.P.; Biesterfeld, S.; Kasperk, R.; Keimer, R.; Füzesi, L.; Schumpelick, V. (Aachen, Germany)

98174 Adenovirus-Mediated Insulin Gene Transfer Improves

Post-Hepatectomized Conditions in Diabetic Rats

Matsumoto, T.; Yamaguchi, M.; Matsumiya, A.; Kuzume, M.; Sakai, H.; Kumada, K. (Yokohama, Japan)

98175 Glutathion s-Transferase as Parameter for Detection of In Vivo Liver I/R Injury in the Rat Heijnen, B.H.M.; Straatsburg, I.H.; Gouma, D.J.; van Gulik, T.M. (Amsterdam, Netherlands)

99176 Protective Effects of Herbimycin A on Hepatic Radical Injury

Sakai, H.; Yamaguchi, M.; Kuzume, M.; Matsumoto, T.; Matsumiya, A.; Kumada, K. (Yokohama, Japan)

99177 Distal Spleno Renal Shunt in Management of Bleeding Esophagogastric Varices. 20 Year Experience 600 Patients Fathy, O.; El-Hak, N.G.; El-Ebidy, G.; Zid, M.A.; abo El-Enin, A.; Ezzat, F. (Cairo, Egypt)

100178 Selective Binding of Liver Sinusoidal Lymphocytes to Primary but not Metastatic Liver Tumors in Humans

Lukomskal, B.; Dluzniewska, J.; Polanski, J.; Olszewski, W.L. (Warsaw, Poland)

100179 Rectoanal Inhibitory Reflex in Constipated and Incontinent Patients

Kaur, G.; Gardiner, A.; Duthie, G.S. (Hull, United Kingdom) 
Gastrointestinal Surgery IV

101180 Modulation of the Colonic Bacterial Flora Affects Differently Bacterial Translocation and Liver Injury in an Acute Liver Injury Model Adawi, D.; Molin, G.; Ahrné, S.; Jeppsson, B. (Malmö, Sweden)

101181 Evaluation of Intestinal Microcirculatory Disorders by Spectroscopy in Experimental Colitis

Butz, R.L.; Buhr, H.-J.; Foitzik, T. (Berlin, Germany)

102182 Guideline Development for the Interface General Practitioner/Clinical Surgeon with a Score for Acute Appendicitis

Sitter, H.; Zielke, A.; Rampp, T.; Hasse, C.; Rothmund, M.; Lorenz, W. (Marburg, Germany)

102183 Altered Transepithelial Transport in Inflammatory Bowel Disease

Schürmann, G.; Brüwer, M.; Klotz, A.; Schmid, K.W.; Senninger, N.; Zimmer, K.P. (Münster, Germany)

103184 Interleukin-1 $\beta$ and Reactive Oxygen Species Lead to Enhanced Tumour Take After Surgery

van Rossen, M.E.E.; Aalbers, A.G.J.; Marquet, R.L.; Jeekel, J.; van Eijck, C.H.J. (Rotterdam, The Netherlands)

104185 A Pathophysiological Study of the Effects of Floppy Nissen

Fundoplication (FNF) and the Influence of Crural Repair and Fundal Mobilisation

Farhat, S.; Watson, A.; Winslet, M.C. (London, United Kingdom)

104186 A Study of the Mode of Action of the "Phsyiological" Anti-Reflux Procedure (PARP) and the Relative Contribution of its Components to Competence

Farhat, S.; Watson, A.; Winslet, M.C. (London, United Kingdom)
Microvascular and Reconstructive Surgery

105187 MRI-Guided Tumor Resections

Schroeder, T.; Meuli-Simmen, C.;

Romanowski, B.J.; Debatin, J.F.; von

Schulthess, G.K.; Meyer, V.E. (Zürich,

Switzerland)

105188 Sentinel Node Biopsy in Breast Cancer - The Cardiff Experience

Clarke, D.; Khonji, N.; Daoud, R.; Sweetland, H.; Evans, W.; Rees, J.; Mansel, R. (Cardiff, United Kingdom)

106189 Influence of Arterial Oxygen and Carbon Dioxide Pressure on the Microcirculation of Critically Perfused Peripheral Tissues

Strobel, O.; Rücker, M.; Vollmar, B.; Rösken, F.; Menger, M.D. (Homburg/Saar, Germany)

107190 Orbitopalpebral Reconstruction Using Prelaminated and Prefabricated Flaps

Ocampo Pavez, C.; Geishauser, M.; Klöppel, M.; Biemer, E. (Munich, Germany)

108191 Phenotypic Characteristics of Lymphocyte Subsets Isolated from Rat Liver with Colon Cancer Metastases Durowicz, S.; Dlużniewska, J.; Laszuk, D.; Olszewski, W.L.; Lukomska, B. (Warsaw, Poland)

108192 Selective Culture of Newborn and Adult Rat Schwann Cells with a Serum-Free Medium

Shen, Z.-L.; Berger, A.; Hierner, R.; Walter, G.F. (Hannover, Germany)

109193 Vascular Freezing, Healing Consequences of End-To-End Anastomoses in the Rat Femoral Artery; Vascular Freezing does Induce Intimal Hyperplasia

Borg, D.H.; Werker, P.M.N.; Franken, J.P.M.; Kon, M.; Borst, C. (Utrecht, The Netherlands) 
109194 Vein Graft Versus Lymphatic or PTFE Interpositioned Shunts in Reconstructive Lymphatic Microsurgery: Experimental and Clinical Models

Campisi, C.; Boccardo, F.; Zilli, A.; Borrelli, V. (Genoa, Italy)

Miscellaneous

110195 Leukocyte Accumulation is Enhanced in iNOS-Deficient Mice with Antigen-Induced Arthritis

Veihelmann, A.; Hofbauer, A.; Refior, H.J.; Krombach, F.; Messmer, K. (Munich, Germany)

110196 Th1-/Th2-Like Cytokine Profiles of Human CD8+ T-Cells: A Valid Predictor for Survival After Major Burn Trauma

Zedler, S.; von Donnersmarck, G.H.;

Schildberg, F.W.; Faist, E. (Munich, Germany)

111197 Non-Operative Management in Cases with Blunt Splenic Injury

Köksal, N.; Uzun, M.A.; Müftüoğlu, T.;

Günerhan, Y.; Kurt, R. (Istanbul, Turkey)

111198 Redistribution of Blood Flow within the Small Intestinal Wall in Septic Shock

Hiltebrand, L.; Banic, A.; Sigurdsson, G.H. (Switzerland)

112199 Is Esophageal Adenocarcinoma Induced by Endogenous Nitroso Bile Acids?

Fein, M.; Fuchs, K.-H.; Diem, S.; Herderich, M. (Würzburg, Germany)

112200 Enteral Glutamine and Intestinal Trophism After Surgery: Effect on Bacterial Translocation and TNF $\alpha$ Levels

García-Caballero, M.; Martinez-Moreno, M.; Meléndez, S.; Moríñigo, M.A.; Ruiz, J.; Rius, F.; Villagrasa, E.; Toval, J.A.; Garcia-Ceballos, A. (Málaga, Spain)
113201 Surgical Defunctioning Enhances Intestinal Permeability and Mortality after Colon Anastomosis in the Rat

Månsson, F.; Fork, T.; Jeppsson, B.;

Thoclaclus, H. (Malmö, Sweden)

For Abstracts 202 and 203 see page 234.

Video Presentations

Session I

114 VP1 Auxiliary Partial Orthotopic Liver Transplantation (APOLT) in Rats

Palmes, D.; Freise, H.; Spiegel, H.U. (Münster, Germany)

114 VP2 Radiofrequency Ablation of Primary and Secondary Malignant Liver Tumors

Gantert, W.A.; von Flüe, M.; Wildisen, A.; Patti, M.G.; Way, L.W. (Luzern, Switzerland; San Francisco, Calif., USA)

115 VP3 Gasless Laparoscopic Cholecystectomy in 1000 Cases: An Alternative to the Pneumoperitoneum Nande, G.A.; Shrikhande, S.V. (Mumbai, India)

115 VP4 Video Assisted Blunt Dissection for the Patients with the Stage O-IIA Esophageal Carcinoma

Iwasa, Y.; Iwasa, M.; Yamamoto, A.; Ohmori, Y.; Kume, M.; Ogoshi, S. (Kochi, Japan)

116 VP5 Laparoscopic Incision Hernia Tense-Free Repair with Goretex Mesh (GM)

Habib, E.; Elhadad, A. (Aulnay-Sous-Bois, France)

116 VP6 Curative Operation for the Renal Carcinoma Involving Hepatic Inferior Vena Cava - Combined Resection of IVC and Reconstruction

Takahama, T.; Kanai, F.; Onishi, K. (Saitama, Japan) 
117 VP7 Experiences with Laparoscopic Splenectomy for ITP Syndrome

Tihanyi, T.F.; Nehéz, L.; Friedman, G. (Budapest, Hungary)

117 VP8 Intraoperative Endoscopy in Laparoscopic Myotomy

Gardovskis, J.; Ambalovs, G.; Pokrotnieks, J. (Riga, Latira)

Session II

118 VP9 Three Dimensional Image Analysis to Facilitate Safe Liver Resection Using Minimally Invasive Surgical Techniques

Sutton, C.D.; White, S.A.; Berry, D.P.;

Mulcahy, K.; Barrie, W.W.; Dennison, A.R.

(Leicester, United Kingdom)

118 VP10 Selectin Blockade Improves Liver Microcirculation in a Rabbit Hepatic Ischemia Reperfusion Model - An Intravital Microscopic Study

Carvalho, G.L.; Wakabayashi, G.; Namihira, T.; Shimazu, M.; Brandt, C.T.; Kitajima, M. (Tokyo, Japan)

119 VP11 Combined Resection of the Portal Vein at the Hepatic Hilus for the Bile Duct Carcinoma - the Procedure and its Further Evaluation Takahama, T.; Kanai, F.; Onishi, K. (Saitama, Japan)

119 VP12 Sentinel Node Biopsy in Breast Cancer

Clarke, D.; Khonji, N.; Daoud, R.; Sweetland, H.; Evans, W.; Rees, J.; Cass, M.; Bellamy, K.; Mansel, R. (Cardiff, United Kingdom)

120 VP13 A New Technique for Minimally Invasive Coronary Revascularization Riess, F.-Ch.; Bleese, N.; Riess, A.G. (Hamburg, Germany)
120 VP14 Video-Assisted Neck Surgery (VANS): Endoscopic Resection for Three Cases of Micro-Papillary Carcinoma of the Thyroid with a Very Minimal Neck Wound Using the Gasless Anterior Neck Lift

Method - A Comparison with 30 Benign Thyroid and Parathyroid Tumors

Shimizu, K.; Akira, S.; Kitamura, Y.; Kitagawa, W.; Akasu, H.; Takatsu, K.; Araki, T.; Tanaka, S. (Tokyo, Japan)

121 VP15 Massive Xiphopubic Eventroplasty by Laparoscopy with a New Personal Technique

Carbajo, M.A.; Garcla-Caballero, M.; Martin, J.I.; Blanco, J.J.; Delacuesta, M.; Martin, F.;

Toledano, M. (Málaga, Spain)

122 VP16 Staging Laparoscopy in Pancreatic Cancer

Biru, D.; Poch, B.; Orth, K.; Beger, H.G. (Ulm, Germany)

Poster Presentations

Gastrointestinal Surgery I

123 PP1 Changes of Polyamines after Gastrointestinal Surgery with Enteral or Parenteral Nutrition

Iwasa, M.; Iwasa, Y.; Ogoshi, S. (Kochi, Japan)

123 PP2 Pressure Gradients in Constipated and Incontinent Patients

Kaur, G.; Gardiner, A.; Duthie, G.S. (Hull, United Kingdom)

124 PP3 A New Method of Assessing Sphincter Function in Incontinent and Constipated Patients

Kaur, G.; Gardiner, A.; Duthie, G.S. (Hull, United Kingdom)

124 PP4 Constipation - A Scoring System for the Underdogs

Kaur, G.; Gardiner, A.; Lee, P.W.R.;

Monson, J.R.T.; Duthie, G.S. (Hule, United

Kingdom) 
125 PP5 The Analysis of the Surgical Complication for Elderly Patients with Gastric Cancer

Matsuo, K.; Honda, O.; Hiraga, K.;

Maruyama, K.(Tokyo, Japan)

125 PP6 T $\gamma \delta$ Cell Count may Help to Prognose Postoperative Recovery after Gastrointestinal Surgery

Gryglewski, A.; Szczepanik, M.; Majcher, P.; Popiela, T.; Ptak, W. (Kraków, Poland)

126 PP7 Palliative Cryosurgery of Liver Tumours

Rohr, M.; Endrigkeit, S.; Arkan, C.; Nier, H. (Offenbach, Germany)

126 PP8 Influence on Tumor Recurrence after Transanal Excision of Stage I Rectal Cancer in Comparison with Radical Resection

Ambacher, T.; Kasperk, R.; Schumpelick, V. (Aachen, Germany)

127 PP9 Surgical Strategy for Primary Intestinal Non-Hodgkin-Lymphomas

Schmidt, W.U.; Heise, W.; Daum, S.; Müller, F.P.; Röher, H.D.; Verreet, P.R. (Krefeld, Germany)

127 PP10 Outcome and Strategy for the Recurrence of Gastric Cancer

Kobayashi, O.; Saito, M.; Yoshikawa, T.;

Tsuburaya, A.; Sairenji, M.; Motohasi, H.

(Yokohama, Japan)

Gastrointestinal Surgery II

127 PP11 Sutureless BAR Anstomosis - 100 Consecutive Cases

Penka, I.; R. Šefr, Tuma, J. (Brno, Czech Republic)

128 PP12 High-Dose Locoregional Hypoxic Chemotherapy with Hemofiltration for Advanced Cancer

Valieri, L.; Morsiani, E.; Fiorentini, G.; Marzola, M.; Vinci, D.; Kabbara, S.; Azzena, G. (Ferrara, Italy)

129 PP13 The Role of NORs in the Diagnostic Differentiation of Tumours of the Colon

Zalewski, B.; Famulski, W.; Famulska, D. Jabłońska, E.; Piotrowski, Z. (Białystok, Poland)
129 PP14 Alterations in the Early Postoperative Cytokine Response after Preoperative Pentoxyfylline Administration

Popiela, T.; Szczepanik, A.M.; Wordliczek, J.; Czupryna, A.; Siedlar, M.; Solecki, R.;

Zembala, M. (Cracow, Poland)

130 PP15 Withdrawn

130 PP16 Thirteen Year Experience of Surgical Treatment for Oesophageal Cancer

Sutton, C.D.; White, S.A.; Robertson, G.S.M.; Berry, D.P.; Barr, C.; Horsburgh, T.; Veitch, P.S. (Leicester, United Kingdom)

131 PP17 Covered Self-Expanding Oesophageal Stents (SEMS) in the Treatment of Anastomotic Leak Following Oesophagectomy

Shah, K.; White, S.; Sutton, C.; Veitch, P. (Leicester, United Kingdom)

131 PP18 The Role of Doppler Perfusion Index (DPI) in the Detection of Colorectal Liver Metastases

Komborozos, V.; Lapatsanis, D.; Kalogeris, M.; Skrekas, G.; Viha, K.; Piperopoulos, P.; Yannopoulos, P. (Athens, Greece)

132 PP19 Blunt Injury of the Diaphragm Zoricic, D.; Mirkovic, M.; Cvijanovic, R.; Milosevic, P.; Djermanov, Z.; Veljkovic, R. (Novi Sad, Yugoslavia)

132 PP20 Malignant Esophageal Fistula: A Surgical Challenge

Patrinou, V.; Filos, K.; Petsas, T.; Vagianos, C.; Dougems, D. (Patras, Greece)

Gastrointestinal Surgery III

133 PP21 Hashimoto's Like Lymphocytic Proliferation in Post Chernobyl and Fap Associated Papillary Thyroid Carcinomas

Baldi, C.; Loré, F.; Toti, P.; Spini, D.; Laurini, L.; Montalto, G.; Raffaelli, N.; Cetta, F. (Siena, Italy)

Eur Surg Res Vol. 31, Suppl. 1, 1999 XIX 
133 PP22 Changes in Treatment Strategy of Primary Gastric Lymphoma (PGL): A Report of 42 Cases

Kitsakos, A.; Roukos, D.H.; Ioannou, H.; Batsis, Ch.; Markouizos, G.; Stylianides, G. Kappas, A.M. (Ioannina, Greece)

134 PP23 Distal Gastric Cancer: Should Be a Standard Total Gastrectomy Performed for the Dissection of Right and Left Cardial Lymph Nodes

Kitsàkos, A.; Paraschou, P.; Roukos, D.H.; Stylianides, G.; Batsis, Ch.; Markouizos, G.; Lorenz, M. (Frankfurt, Germany and Ioannina, Greece)

134 PP24 Gastrectomy for Early Gastric Cancer (EGC): A 10-Year Long-Term Follow-Up Study

Roukos, D.H.; Kitsakos, A.; Paraschou, P.; Lorenz, M. (Frankfurt, Germany and Ioannina, Greece)

135 PP25 Prognostic Value of D2-Gastrectomy Evaluated with a New Concept

Roukos, D.H.; Paraschou, P.; Kitsakos, A.; Lorenz, M.; Encke, A. (Frankfurt, Germany and Ioannina, Greece)

135 PP26 Partial Splenic Embolization for Bleeding from Portal Hypertensive Gastropathy

Shibuya, S.; Takase, Y.; Sawano, T.;

Kawashima, T.; Chikamori, F. (Tsukuba City, Japan)

135 PP27 The Choice of

Esophagojejunostomy Method in Gastrectomy

Ershov, V.; Rybinsky, A.; Kukosh, M. (Nizhni Novgorod, Russia)

Vascular and Cardiac Surgery I

136 PP28 Prevention of Neointimal Proliferation by Immunosuppression in Synthetic Vascular Grafts Walpoth, B.H.; Pavlicek, M.; Celik, B.; Nicolaus, B.; Schaffner, Th.; Althaus, U.; Morris, R.E. (Bern, Switzerland, and Palo Alto, Calif, USA)
136 PP29 Balloon Angioplasty and Stenting in Mechanically Reconstructed Arteries

Dimakakos, P.B.; Kotsis, T.E.; Pafiti, A.; Doufas, A.G.; Tsiligiris, B.; Mourikis, D. (Athens, Greece)

137 PP30 Angioscopy-Assisted in-situ Saphenous Vein Bypass: 22-Month Follow-Up

Tošenovský, P.; Adamec, M.; Janoušek, L.; Ryska, M. (Prague, Czech Republic)

137 PP31 Postexercise Activation of Neutrophils in Claudicants after Successful Revascularisation Wysocki, A.; Drożdż, W.; Panck, J. (Cracow, Poland)

138 PP32 Red Cells Antioxidant State During Treadmill Exercise Program in Claudicants Drożdż, W.; Wysocki, A.; Panek, J. (Cracow, Poland)

138 PP33 Activation of Neutrophils in the Claudication Patients

Drożdż, W.; Wysocki, A.; Panek, J. (Cracow, Poland)

139 PP34 The Role of Reactive Oxygen Species in the Aortic Aneurysms Formation

Oszkinis, G.; Krasiński, Z.; Pukacki, F.; Gabriel, M.; Krauss, H. (Poznań, Poland)

139 PP35 Effect of Cryopreservation on Elastic Properties of Aortic and Venous Allografts

Pukacki, F.; Jankowski, T.; Grajek, A.; Gabriel, M.; Oszkinis, Z. Krasiński, Zapalski, S. (Poznań, Poland)

$140 \quad$ PP36 Vascular Staplers in Experimental Liver Transplantation - Improvement in Early Patency

Mehrabi, A.; Golling, M.; Schäffer, F.; Jahnke, C.; Weiss, G.; Kraus, Th.; Herfarth, Ch.; Klar, E. (Heidelberg, Germany) 
140 PP37 In Vitro and in vivo Evaluation of a Transaortic Pulsatile Left Ventricular Assist Device (Heart Ranger)

Imanishi, K.; Imachi, K.; Yoshito, H.; Tsutsui, N.; Sueda, T.; Matuura, Y. (Hiroshima, Japan)

141 PP38 Application of a Newly Synthesized Thrombin Inhibitor as an Anticoagulant for Left Ventricular Assist Device (LVAD)

Takahama, T.; Kanai, F.; Onishi, K. (Saitama, Japan)

141 PP39 Biomechanics of the Carotid Artery after TEA-Dynamic in Vitro Evaluation

Kasprzak, P.M.; Schmitz-Rixen, Th. (Regensburg, Germany)

Minimally Invasive Surgery I

142 PP40 Laparoscopy in Differential Diagnostics of Acute Abdominal Pain on Female Patients

Martinsons, A.; Pavars, M.; Ribenieks, R.; Gardovskis, J. (Riga, Latvia)

142 PP41 Adhesion Formation after Laparoscopic Cholecystectomy. A Prospective Trial Versus Open Cholecystectomy

Polymeneas, G.; Theodosopoulos, Th.; Stamatiades, A.; Kourias, E. (Athens, Greece)

143 PP42 Diagnostic Laparoscopy in Young Female with Suspected Acute Appendicitis: How Accurate is it? Chung, T.K.M.; Chick, W.K.; Tse, C.C.W.; Chia, N.H.; Hwang, J.S.T. (Hong Kong, China)

143 PP43 Instrument's Wear and Repair and Contamination - A Prospective Clinical Trial 10/95-9/96

Fengler, Th.W.; Pahlke, H.; Kraas, E. (Berlin, Germany)

144 PP44 Management of Laparoscopic-Related Bowel Injuries El-Banna, M.; AbdEl-Aty, M.; ElMeteini, M.; Aly, S. (Cairo, Menoufia, Egypt)
144 PP45 Functional Comparison of Multifire Clip Appliers in Laparoscopic Surgery

Gantert, W.A.; von Flüe, M.; Wildisen, A.; Patti, M.G.; Way, L.W.; (Luzern, Switzerland, San Francisco, Calif., USA)

145 PP46 Is the Total Endoscopic Preperitoneal Hernioplastic (TEP) Used Only for Repair of Rezidiv-Hernia after Conventional Herniotomy According to the Learning Curve a Good Idea?

Klag, J.; Schröder, D.; Reimuth, S.; Kreuch, R.G. (Eschwege, Germany)

146 PP47 Spectrum of Indications for the Endodock Applicator for Application of a Fibrin Glue-Coated Collagen Fleece

Scheyer, M.; Zimmermann, G. (Feldkirch, Austria)

146 PP48 Voice Controlled Robotic Arm in Endoscopic Surgery

Köninger, J.; Butters, M. (Bietigheim-Bissingen, Germany)

146 PP49 Suspected Acute Appendicitis in 500 Patients: The Introduction of Diagnostic Laparoscopy and Laparoscopic Appendicectomy Moberg, A.-C.; Montgomery, A. (Malmö, Sweden)

Minimally Invasive Surgery II

147 PP50 Antibiotic Prophylaxis for Laparoscopic Cholecystectomy Endzinas, Z. (Kaunas, Lithuania)

147 PP51 Microlaparotomy Cholecystectomy Rozsos, S.E.; Szira, P.T. (Kaposvar, Hungary)

148 PP52 Laparoscopic Cholecystectomy: Calot Triangle First Wide Opening Technique

Habib, E.; Elhadad, A. (Aulnay-Sous-Bois, France)

148 PP53 Withdrawn 
149 PP54 The Effect of UFT in Colorectal Cancer Using Expression of CD44 and Apoptosis

Tachikawa, D.; Arima, S.; Futami, K.;

Iwashita, A. (Chikushino, Japan)

149 PP55 Long-Term Effects of Interstitial Laser Coagulation (ILC) with Portal Inflow Occlusion: Central vs. Peripheral Lesions in a Porcine Model Heisterkamp, J.; van Hillegersberg, R.; Ijzermans, J.N.M. (Rotterdam, The Netherlands)

150 PP56 Distant Surgery Treatment Results of Gastroesophagitis Reflux Disease

Puchkov, K.; Filimonov, V.; Martinov, M. (Ryazan, Russia)

150 PP57 Laparoscopic Cholecystectomy in Patients with Previous Abdominal Surgery

Georgescu, St.; Vintila, D.; Stratan, I.; Plesa, C. (Iasi, Romania)

151 PP58 Laparoscopic Cholecystectomy Experience with 1500 Cases

Fathy, O.; Abd El-Wahab, M.; El Hak, N.G.; El-Ebiedy, G.; Abu Zied, M.; Abu El-Enien, A.; El-Fiky, A.; Sultan, A.; Anwar, N. ; Ezat, F. (Mansoura, Egypt)

Organ and Tissue Transplantation I

151 PP59 "Combi-Effect” after Xenogeneic Discordant Transplantation

Kelm, C.; Buhr, J.; Henneking, K.; Schwemmle, K. (Giessen, Germany)

152 PP60 Celsior ${ }^{\circledR}$ in Experimental Pancreas Transplantation

Baldan, N.; Parise, P.; Furian, L.; M. Lo Savio, Valente, M.L.; Calabrese, F.; Venturini, R.; Girotto, A.; Rigotti, P. (Padova, Italy)

152 PP61 Technique of Immunoadsorption in Orthotopic Xenotransplantation of Pig Hearts in Baboons

Brenner, P.; Reichenspurner, H.; Schmoeckel, M.; Wimmer, C.; Rucker, A.; Eder, V.; Hinz, M.;

Felbinger, T.; Müller-Höcker, J.; Seidel, D.;

Hammer, C.; Reichart, B. (Munich, Germany)
153 PP62 Influence of Ischemic Time on Hyperacute Xenograft Rejection

Brenner, P.; Hinz, M.; Huber, H.;

Schmoeckel, M.; Reichenspurner, H

Hammer, C.; Reichart, B. (Munich, Germany)

154 PP63 The Role of White Blood Cells in Post-Heart Transplant Coronary Vasculopathy. The Effect of the Immunosuppressive Treatment Jurado, F.; Pascual, G.; G ${ }^{a}$-Honduvilla, N.; Golitsin, A.; J. Buján, Bellón, J.M. (Madrid, Spain)

154 PP64 Protein Synthesis in Transplanted Bone

Fraitzl, C.R.; Leunig, M.; Demhartner, T.J.; Sckell, A.; Ganz, R.; Hofstetter, W. (Bern, Switzerland)

155 PP65 24, 48 and 72 h Cold Storage of the Porcine Pancreas prior to Autotransplantation

Hesse, U.J.; Troisi, R.; Jacobs, B.; Berrevoet, F.; De Laere, S.; Maene, L.; Vanden Broucke, C.; de Hemptinne, B. (Gent, Belgium)

155 PP66 Interleukin-8 and its Implication for Transplant Rejection

Diller, R.; Dietl, K.-H.; Winde, G.; Senninger, N.; Spiegel, H.-U. (Münster, Germany)

156 PP67 Graft Prolongation after Conditioned Immunosuppression is Mediated via Splenic Innervation

Schult, M.; Exton, M.S.; Donath, S.; Nagel, E.; Westermann, J.; Schedlowski, M. (Hannover, Germany)

157 PP68 Pretransplant Viability of Liver Grafts is Improved by Graduated Addition of DMSO to University of Wisconsin Solution (UW) for Hypothermic Storage Banafsche, R.; Djamaseb, A.; Nobiling, R.; Herfarth, C.; Klar, E. (Heidelberg, Germany) 
Organ and Tissue Transplantation II

158 PP69 Comparison between U.W. and Celsior Solution on Morphology and Viability of Rat Aorta after Cold Storage

Nardo, B.; Cavallari, G.; Catena, F.; Santoni, B.; Turi, P.; Giordano, E.; Pasquinelli, G.; Badiali de Giorgi, L.; Faenza, A.; Cavallari, A. (Bologna, Italy)

158 PP70 Matrix Metalloproteinase (MMP) and Cytokine Expression in Acute Wound Fluid

Leaper, D.J.; Baker, E.A.; Bergin, F.G. (Cleveland, United Kingdom)

159 PP71 Preclinical in vitro testing of novel radial-flow bioreactor for hybrid artificial liver support

Valieri, L.; Morsiani, E.; Puviani, A.C.; Lodi, A.; Pazzi, P.; Galavotti, D.; Brighenti, L.; Azzena, G. (Ferrara, Italy)

160 PP72 Dynamics of Regulatory T Cells in Infectious Tolerance Pathway in Sensitized Recipients

Onodera, K.; Sakata, H.; Kato, K.; Kasai, S.; Kupiee-Weglinski, J.W. (Asahikawa, Japan)

160 PP73 Measurement of Phagocytic Chemiluminescence after Splenectomy and Autotransplantation of the Spleen in Experimental Animals

Furka, I.; Mikó, I.; Sipka, S.; Antal-Szalmás, P.; Furka, A.; Szabó, Gy.; Kovács, J.; Matesz, K.; Kappelmayer, J.; Góth, L.; Oláh, A.; Serfõzõ, J.; Incze, D. (Debrecen, Hungary)

161 PP74 Reserved Functional Integrity of the Liver after Exposure to High-Pressure

Takahashi, T.; Takahashi, Y.; Sakamoto, I.; Fujiu, T.; Kakita, A.; Yamashina, S.; Takazawa, Y.; Muratsubaki, R. (Toyama, Japan)

161 PP75 Experimental Study on the Extrinsic Hepatic Reinnervation following Liver Transplantation in Rats

Sakamoto, I.; Takahashi, T.; Takahashi, Y.; Hayashi, K.; Tadokoro, F.; Iino, Z.-I.; Ito, Y.; Sato, K.; Kakita, A. (Sagamihara, Japan)
162 PP76 Allotransplantation of Hepatocytes into the Spleen Following Liver Plus Kuppfer Cells Inoculation into the Thymus

García-Alonso, I.; Portugal, V.; Pereira, J.G.; García Ruiz, A.; Méndez, J. (Lejona, Spain)

162 PP77 Variable Ex Vivo Whole Blood Isolated Lung Perfusion System

Schelzig, H.; Simon, F.; Storck, M.; Brehm, W.; Abendroth, D. (Ulm, Germany)

163 PP78 Preoperative Application of Steroids in Kidney Transplantation Strik, M.W.; Klüter, H.; Bruch, H.-P.; Fricke, L. (Lübeck, Germany)

163 PP79 Harvest and Preservation Injury of Small Bowel Grafts in Rats: Influence of the Surgical Technique and Preservation Solutions

Emparan, C.; Garcia-Alonso, I.; Gruber, S.; Stepkowski, S.; Mendez, J.; Kahan, B.D. (Bilbao, Spain)

164 PP80 Significance of Blood Group Incompatibility in Porcine Heart Transplantation

Walpoth, B.H.; Hauser, S.P.; Nicolaus, B.; Vögeli, P.; Carrel, T.; Althaus, U. (Bern and Zürich, Switzerland)

164 PP81 Long Term Consequences of Acute Liver Allograft Rejection Abou El-Ella, K.; Shokouh, A.; Hathaway, D.; Gaber, A.O. (Alexandria, Egypt)

Orthopedics and Traumatology I

165 PP82 The Osteogenic Ability of Free Periosteal Autografts in Tibia Fractures with Severe Soft Tissue Damage: An Experimental Study Reynders, P.; Becker, J.H.R. (Leuven, Belgium, Pretoria, South Africa)

165 PP83 Widespread Sepsis Following Secondary Intramedullary Nailing of a Pin Tract Infection

Clasper, J.C.; Bowley, D.M.G.; Watkins, P.E. (Salisbury, England) 
166 PP84 Results and Problems in the Treatment of Distal Femur Fractures Goldhahn, J.; Bach, O.; Bühler, M.; Hehli, M. (Davos, Switzerland; Jena, Germany)

166 PP85 Blunt Arterial Trauma: Biomechanics and Pathomechanism of Thrombosis

Scola, E. (Neumarkt, Germany)

167 PP86 Posttraumatic Edema of Lower Limbs - Lymphatic and Venous Changes

Szczesny, G.; Olszewski, W.L. (Warsaw, Poland)

167 PP87 Suitability of Different Lasers in Experimental Spinal Hemiepiphysiodesis

Lang, R.D.; Rumpf, C. (Heidelberg, Germany)

168 PP88 A New Detailed CT

Classification Based on Traumatic Coma Data Bank

Sakamoto, T.; Takayanagi, K.; Koseki, K.; Sugimoto, K.; Aruga, T. (Tokyo, Japan)

168 PP89 A Large Scales of Clinical Study for Geriatric Trauma Patients in Level I Trauma Centers in Japan K. Sugimoto, Takayanagi, K.; Koseki, K.; Aruga, T.; Sakamoto, T.; Koido, Y. (Tokyo, Japan)

169 PP90 Effect of Different Processing Modalities on Cytotoxicity and Biocompatibility of Shape Memory Alloys

Pommer, A.; Köller, M.; Hahn, M.P.; Muhr, G. (Bochum, Germany)

169 PP91 The Unstable Complex Fracture of the Proximal Femur: Successful Osteosynthesis with the Long Gamma Nail

Marti, W.R.; Giger, R.; Keller, H.; Schnider, A.; Berbig, R.; Brunnschweiler, D.; Metzger, U. (Zürich, Switzerland)
170 PP92 Reperfusion Injury Following Tourniquet Ischaemia in Traumatology

Borsiczky, B.; Szántó, Z.; Wiegand, N.; Rõth, E.; Nyárády, J. (Pécs, Hungary)

170 PP93 Microhemodynamics and Oxygenation in Ischemic Skin Flaps after Trauma and Surgery

Erni, D.; Sakai, H.; Tsai, A.G.; Banic, A.; Intaglietta, M. (San Diego, Calif., USA; Bern, Switzerland)

Shock, Microcirculation and Reperfusion Injury I

171 PP94 Suppression of Myocardial Ischemia Reperfusion Injury by Thermo-Stress

Inui, K.; Shimazaki, Y.; Takahashi, T.; Sugimoto, T.; Sotoda, Y. (Yamagata, Japan)

172 PP95 Granulocyte Dysfunction after Polytrauma: Role of Immature Cells Köller, M.; Schildhauer, T.; Hahn, M.P.; Muhr, G. (Bochum, Germany)

172 PP96 A New Filtration Device for a Robotic System to Determine Organ Perfusion with Fluorescent Microspheres

Thein, E.; Raab, S.; Harris, A.G.; Kleen, M. Habler, O.; Meisner, F.; Pape, A.; Messmer, K. (Munich, Germany)

173 PP97 Reduction of Hepatic Ischemia/Reperfusion-Induced Microvascular Disturbances by Heat Shock Pretreatment in an in situ Rat Liver Perfusion Model

Terajima, H.; Kondo, T.; Enders, G.; Hammer, C.; Thiäner, A.; Messmer, K. (Munich, Germany)

173 PP98 Which Method for Analysis of Gastric Tonometric Data is Most Sensitive in Hemorrhagic Shock?

Meisner, F.; Kleen, M.; Habler, O.; Kemming, G.; Pape, A.; Meßmer, K. (Munich, Germany) 
174 PP99 Are Calculated and Measured $\mathrm{VO}_{2}$ Interchangeable Methods during Inhalative Anesthesia and in the Presence of Supply Dependency?

Kemming, G.; Habler, O.; Kleen, M.; Meisner, F.; Tillmanns, J.; Pape, A.; Meier, J.; Wojtezyk, C.; Bottino, D.; Messmer, K. (Munich, Germany)

175 PP100 Effect of Diaspirin Cross-Linked Hemoglobin on Normal and Postischemic Microcirculation of the Pancreas

von Dobschuetz, E.; Hoffmann, T.; Messmer, K. (Munich, Germany)

175 PP101 Endothelin-1 Induces Mast Cell Degranulation through Endothelin - A Receptor Activation Kaszaki, J.; Szalay, L.; Dargai, O.; Nagy, S.; Boros, M. (Szeged, Hungary)

176 PP102 Dopexamine vs Dopamine on Pulmonary Function in Aortic Surgery Kotsis, T.E.; Doufas, A.G.; Kostopanagiotou, G.; Hondroudaki, J.E.; Dimakakos, P.B. (Athens, Greece)

176 PP103 Intermittent Clamping Increases Ischemic Tolerance During Warm Ischemia/Reperfusion

Zapletal, C.; Maksan, S.-M.; Weiss, G.; Gebhard, M.M.; Herfarth, Ch.; Klar, E. (Heidelberg, Germany)

Shock, Microcirculation and Reperfusion Injury II

177 PP104 Mithcondrial Oxidative Injury in Rat Fatty Liver Exposed to Ischemia-Reperfusion Injury

Nardo, B.; Caraceni, P.; Grattagliano, I.;

Catena, F.; Santoni, B.; Turi, P.; Cavallari, G.; Domenicali, M.; Dall'Agata, M.;

Vendemiale, G.L.; Altomare, E.; Bernardi, M.; Cavallari, A. (Bologna, Italy)

178 PP105 Ethibloc ${ }^{\mathrm{R}}$ Application Caused Microcirculatory Shut Down, Pancreas Necrosis and Inflammation Plusczyk, T.; Westermann, S.; Menger, M.; Feifel, G. (Homburg/Saar, Germany)
178 PP106 Role of Kupffer Cells in LPS Sensitivity and Cytokine Release in Obstructive Jaundice in the Rat Lázár, G.; Duda, E.; Szakács, J.; Oláh, J.; Balogh, À.; Lázár, G. (Szeged, Hungary)

179 PP107 Can Preconditioning Prevent Apoptosis During Ischemia-Reperfusion in the Intestinal Wall of Laboratory Animals?

Bráth, E.; Kovács, J.; Mikó, I.; Komár, T.; Furka, I. (Debrecen, Hungary)

180 PP108 Microcirculatory Blood Flow in the Pancreas and Liver During Septic Shock

Hiltebrand, L.; Banic, A.; Sigurdsson, G.H. (Berne, Switzerland)

180 PP109 Substance P may Attenuate Gastric Hyperemia by a Mast Cell Dependent Mechanism in the Damaged Mucosa of the Rat Stomach Rydning, A.; Lyng, O.; Aase, S.; Grønbech, J.E. (Trondheim, Norway)

181 PP110 Prolonged Ischemia and Reperfusion Induces Lethal Lipid Peroxidation in the Canine Liver

Fukai, M.; Shimamura, T.; Suzuki, T.; Yokota, R.; Taniguchi, M.; Hayashi, T.; Iida, J.; Magata, S.; Jin, M.B.; Horiuchi, H.; Ogata, K.; Ishikawa, H.; Yamashita, K.; Kishida, A.; Furukawa, H.; Todo, S. (Sapporo, Japan)

181 PP111 Influence on ICG-Kinetics by Endothelin Antagonists after Hepatic Ischemia in Rats

Riesener, K.P.; Matziolis, G.; Kasperk, R.; Hektor, J.; Schumpelick, V. (Aachen, Germany)

182 PP112 Induction of Microvascular Thrombosis is Inhibited by the Polysaccharide Fucoidan in vivo: Role of P- and L-Selectin

Thorlacius, H.; Vollmar, B.; Vesterweber, D.; Menger, M.D. (Freiburg, Germany) 
182 PP113 Tissue Expression of Heat Shock Protein (HSP) 72 and Hemoxygenase-1 (HSP32) after Heat Shock and Ischemic Preconditionings of Rat Livers

Uchinami, H.; Yamamoto, Y.; Kume, M.; Yonezawa, K.; Ishikawa, Y.; Shimahara, Y.; Yamaoka, Y. (Kyoto, Japan)

Shock, Microcirculation and Reperfusion Injury III

183 PP114 Low Wall Shear Rate in Microcirculation of Metastasized Lung Tumor in Anesthetized Mice Funakoshi, N.; Onizuka, M.; Yanagi, K.; Ohshima, N.; Tomoyasu, S.; Yamamoto, T.; Ishikawa, S.; Mitsui, T. (Tsukuba, Japan)

184 PP115 Selectin Blockade Reduces Free Radical Production and Organ Dysfunction, Improving Survival Rate in a Rabbit Hepatic Ischemia Reperfusion Model

Carvalho, G.L.; Wakabayashi, G.; Namihira, T.; Shimazu, M.; Brandt, C.T.; Kitajima, M. (Tokyo, Japan)

184 PP116 Beneficial Effects of Treatment with Antibodies Against Adhesion Molecules in Gut Barrier Failure Caused by Mesenteric Arterial Ischemia and Reperfusion Andersson, R.; Sun, Z.W.; Börjesson, A.; Inghammar, M.; Lasson, Å.; Wang, X.D. (Malmö, Sweden)

185 PP117 Normothermic Pulsatile Oxygenated Rinse of Small Bowel Grafts Ameliorates Reperfusion Injury

Emparan, C.; Garcia-Alonso, I.; Hong, J.; Mendez, J.; Kahan, B.D. (Bilbao, Spain)

185 PP118 Evidence of Free Radical Mediated Reactions after Coronary Angioplasty in Humans

Röth, E.; Késmárky, G.; Vajda, G.; Habon, L.; Lantos, J.; Jaberansari, M.T. (Pécs, Hungary)
186 PP119 Heat-Shock Sparks Signal Transduction Via Phosphatidylcholine Cycles

Suárez, A.; Guisasola,, M.C.; Sánchez, M.J.; Villanueva, F.J.; García-Barreno, P. (Spain)

Molecular Biology I

187 PP120 Differential Display and Direct Reamplification of Messenger RNAs From two Clones of SL 12 Murine Lymphoma with Different Metastatic Pattern

Wong, W.; Holland, T.; Deakin, M. (Keele, United Kingdom)

187 PP121 Local and Systemic Role of Tissue Inhibitor of Matrix Metalloproteinase-1 in Gastric Carcinoma

Yoshikawa, T.; Saitoh, M.; Tsuburaya, A.; Kobayashi, O.; Sairenji, M.; Motohashi, H. (Yokohama, Japan)

188 PP122 The Effect of UFT in Colorectal Cancer using Expression of CD44 and Apoptosis

Tachikawa, D.; Arima, S.; Futami, K.; Iwashita, A. (Chikushino, Japan)

188 PP123 The Role of Apoptosis in Fetal Duodenum Development

Cheng, W.; Tam, P.K.H. (Hong-Kong, China)

189 PP124 Serum Tumour Necrosis Factor-Alpha and Vascular Endothelial Growth Factor: Synergistic Predictors of Development of Metastases in Colorectal Cancer Patients

Chin, K.F.; Topping, K.; O’Hara, R.; Kumar, H.; Greenman, J.; Hartley, J.; MacDonald, A.; Kerin, M.J.; Monson, J.R.T. (Hull, HU16 5JQ, United Kingdom)

189 PP125 CA 242: A New Tumor Marker for Pancreatic Carcinoma

El-Banna, M.; Amer, H.; El-Atrash, O.; Aly, S. (Cairo, Egypt) 
190 PP126 N-Nitrosomethylbenzylamine (NMBA) Treatment in a Transgenic Cyclin D1 Overexpressing Mouse Model Increased the Severity of Esophageal Dysplasia

Müller, A.; Jenkins, T.D.; Odze, R.;

Shahsafaei, A.; Becker, H.; Rustgi, A.K

(Góttingen, Germany)

190 PP127 Effect of Glutamine Administration on Intestinal and Liver Histology in Obstructive Jaundice

Kehagias, J.; Tsamandas, A.C.; Margaritis, V.; Scopa, C.D.; Nikolopoulou, V.; Vagianos, C. (Patras, Greece)

191 PP128 Pathology of Liver Regeneration Following Chemically Induced Periportal and Pericentral Necrosis in Rats

Papalabros, E.; Felekouras, E.S.; Sigala, F.; Salakou, S.; Triantafyllou, A.; Tsamandas, A.C. (Athens, Greece)

191 PP129 Immunohistochemical Detection of bcl-2 Protein in Human Colorectal Carcinoma: Correlation with Tumor Progression and Survival Kakisis, J.; Kouraklis, G.; Delladetsima, I.; Raftopoulos, J.; Karatzas, G.; Gogas, J. (Athens, Greece)

Molecular Biology II

192 PP130 Evaluation of Ki-67 as a Prognostic Marker for Colorectal Cancer

Kouraklis, G.; Kakisis, J.; Delladetsima, I.; Karatzas, G.; Gogas, J. (Athens, Greece)

192 PP131 Retinoblastoma Protein Expression in Follicular Lesions of the Thyroid Gland

Barreiro, F.; Cameselle, J.; Conde, R.; Mena, E.; Reyes, R.M.; Potel, J.; Cainzos, M. (Santiago de Compostela, Spain)
193 PP132 Modified Systemic Cytokine Response after Kupffer Cell Blockade in Acute Pancreatitis in Rats

Gloor, B.; Blinman, T.A.; Schmitter, N.; Uhl, W.; Reber, H.A.; Büchler, M.W. (Irvine, Calif., USA; Bern, Switzerland)

193 PP133 The Prognosis of Esophageal Cancer is Independent on the Presence of Members of the Epidermal Growth Factor Family Berberat, P.; Friess, H.; Fukuda, A.; Tang, W.; Zimmermann, A.; Korc, M.; Büchler, M.W. (Bern, Switzerland)

194 PP134 Liver Pathology after Hepatic Ischemic Damage in Jaundiced Rats Karavias, D.; Tsamandas, A.C.; Tepetes, K.; Mirra, L.; Agriantoni, M.; Androulakis, J. (Patras, Greece)

194 PP135 Topological Analysis of p21 ${ }^{\text {WAFI/CIPI }}$ Expression in Esophageal Squamous Dysplasia

Shirakawa, Y.; Naomoto, Y.; Kimura, M.; Kawashima, R.; Yamatsuji, T.; Hamada, M.; Haisa, M.; Tanaka, N. (Okayama, Japan)

195 PP136 The Influence of 5-Fluorouracil on Cyclin A in Stomach Cancer Cell Lines

Kawashima, R.; Haisa, M.; Kimura, M.; Shirakawa, Y.; Naomoto, Y.; Tanaka, N (Okayama, Japan)

196 PP137 A Study on Changes of Thymidine Phosphorylase and PCNA in the Gastric Cancer Tissues following Preoperative Administration of $5^{\prime}$-DFUR

Yanagi, Y.; Takemura, K.; Nagashima, T.; Kiyoto, K.; Iwata, K.; Higashi, N.; Okamura, R.; Maeda, C.; Tanaka, I.; Yamamura, T.; Hagiwara, M.; Yamaguchi, S.; Takakuwa, T.; Uchikoshi, T. (Kawasaki, Japan) 
196 PP138 Comparative Study on Changes of Thymidine Phosphorylase and Cdc2 by Preoperative Administration of $5^{\prime}$-DFUR in Patients with Gastric Cancer

Kiyoto, K.; Takemura, K.; Nagashima, T.;

Yanagi, Y.; Iwata, K.; Higashi, N.; Okamura, R.;

Maeda, C.; Tanaka, I.; Yamamura, T.;

Hagiwara, M.; Yamaguchi, S.; Takakuwa, T.;

Uchikoshi, T. (Kawasaki, Japan)

197 PP139 Hepatocyte Growth Inhibitory Factor Derived from HTLV-I (+) T

Cell Line is Identical to IL-6

Kawai, Y.; Nakamura, Y.; Taki, Y.; Yamaoka, Y.; Takabayashi, A. (Osaka, Japan)

Molecular Biology III

197 PP140 VEGFR-3 mAb Inhibits Vascular Endothelial Cell Differentiation in vitro

Shimizu, K.; Kubo, H.; Hashi, H.; Awane, M. Takabayashi, A.; Yamaoka, Y. (Kyoto, Japan)

198 PP141 iNOS Induction is Suppressed by PAO at a Step of NF- $\kappa$ B DNA Binding in Hepatocytes

Oda, M.; Sakitani, K.; Inoue, T.; Kwon, A.-H.; Kamiyama, Y.; Ito, S.; Okumura, T. (Osaka, Japan)

198 PP142 Hypoxia and Heat Inhibit iNOS Gene Induction by Different Mechanism in Hepatocytes

Inoue, T.; Kwon, A.-H.; Oda, M.; Itoh, S.; Okumura, T.; Kamiyama, Y. (Osaka, Japan)

199 PP143 Mini-laparoscopic Splenectomy Yuan, R.H.; Yu, S.-C. (Taipei, Taiwan)

199 PP144 Evidence of Promotion of Tumor Cell Proliferation by Migrated Endothelial Cells

Okamoto, H.; Kusama, T.; Fujii, H.;

Matsumoto, Y.; Ohigashi, H.; Ishikawa, O.; Imaoka, S.; Akedo, H. (Yamanashi, Japan)
200 PP145 The Effect of Cytokines Gene Expression on the Invasiveness of Human Hepatocellular Carcinoma Baer, H.U.; Abou-Shady, M.; Friess, H.; Zimmermann, A.; Büchler, M.W. (Bern, Switzerland)

200 PP146 The Influence of TGF- $\beta 1$ on Liver Regeneration and Growth of Hepatocellular Carcinoma in the ACI Rat

Abou-Shady, M.; Friess, H.; Zimmermann, A.; Baer, H.U. (Bern, Switzerland)

201 PP147 Large Induction of the Ect2 Proto-Oncogene in Regenerating Mouse Liver

Sakata, H.; Onodera, K.; Kato, K.; Mito, M.; Kasai, S. (Asahikawa, Japan)

201 PP148 The Effect of Pituitary Adenylate Cyclase-Activating Polypeptide on Ion Transport in Human Colon

Ekelund, M.; Nejdfors, P.; Hallén, M.; Kanje, M.; Weström, B.; Jeppsson, B. (Malmö, Sweden)

202 PP149 Delineation of the Role of CTL/NK Perforin and of Tumor Fas/APO (CD95) in Tumor Immunity Rosen, D.; Li, J.-H.; Keidar, S.; Markon, I.; Orda, R.; Berke, G. (Zerifin, Israel)

Hepatobiliary and Pancreatic Surgery I

202 PP150 Trypsinogen Activation Peptides Assay in the Prediction of Severity of Acute Pancreatitis Perejaslov, A.; Chooklin, S. (Lviv, Ukraine)

203 PP151 Withdrawn

203 PP152 Serum IL-10 and IL-6 Levels in Patients with Resectable Hepatocellular Carcinoma Chau, G.Y.; Lui, W.Y.; Wu, C.W.; Chi, C.W. (Taipei, Taiwan) 
204 PP153 Local Growth Factors in Liver Tissue Regeneration after Partial Hepatectomy in Patients with Benign and Malignant Liver Tumors

Dluzniewska, J.; Polanski, J.; Zajac, L.; Olszewski, W.L.; Lukomska, B. (Warsaw, Poland)

204 PP154 The Role of Multivariate Tumor Marker Analysis in the Surgical Management of Pancreatic Carcinoma and Chronic Pancreatitis Horvath, L.Zs.; Tihanyi, T.F.; Schumann, B.; Flautner, L.E. (Budapest, Hungary)

205 PP155 Monitoring the Effect of Surgical Interventions on the Gallbladder. An Animal Model Petö, K.; Szanyi, A.; Galuska, L.; Furka, I. (Debrecen, Hungary)

205 PP156 New Model of Experimental Reccurent Acute Pancreatitis using Synthetic Hydrophobic Hydroperoxide Kaska, L.; Woźniak, M.; Makarewicz, W.; Sledziński, Z.; Jankowski, K.; Gruca, Z.; Kendo, R. (Gdańsk, Poland)

206 PP157 Spleen Preserving Total Pancreatectomy for Chronic Pancreatitis

Sutton, C.D.; White, S.A.; Robertson, G.S.M.; Berry, D.P.; Rees, Y.; Dennison, A.R. (Leicester, United Kingdom)

206 PP158 Assessment of Endoscopic Stenting for Pancreatic Pseudocysts Sutton, C.D.; White, S.A.; Berry, D.P.; Chillistone, D.; Rees, Y.; Dennison, A.R. (Leicester, United Kingdom)

207 PP159 Immunoreactive Anionic Trypsinogen (irAT) and Immunoreactive Activation Peptide of the Carboxipeptidase B (irCAPAP) in Urine from Patients after Pancreatic Resection

Müller, C.A.; Appelros, S.; Uhl, W.; Büchler, M.W. Borgström, A. (Malmö, Sweden; Bern, Switzerland)
Hepatobiliary and Pancreatic Surgery II

208 PP160 CAPAP and Anionic Trypsinogen in Urine as Severity Predictors in Acute Pancreatitis Müller, C.; Petersson, U.; Appelros, S.; Borgström, A. (Malmö, Sweden; Bern, Switzerland)

208 PP161 Are the Levels of the Immunoreactive Activation Peptide of Carboxypeptidase B (irCAPAP) Increased in Serum and Urine of Patients with Severe Acute Abdominal Disease of non Pancreatic Origin Müller, C.A.; Appelros, S.; Uhl, W.; Büchler, M.W.; Borgström, A. (Malmö, Sweden; Bern, Switzerland)

209 PP162 Changes in Gastric Acidity Following Ductal Decompression Surgery in Chronic Pancreatitis Kovács, I.; Árkossy, P.; Veres, L.; Sápy, P. (Debrecen, Hungary)

209 PP163 Spleen Rupture during Acute Pancreatitis. Cases report. Literature review

Habib, E.; Elhadad, A. (Aulnay-Sous-Bois, France)

210 PP164 Hepatoblastoma Occurs following Different Pathogenetic Pathways in Various Inherited Multitumoral and Metabolic Diseases Montalto, G.; Cetta, F.; Barbarisi, A.; Raffaelli, N.; Zuckermann, M.; Morgese, G.; Rango, C.; Curia, M.C.; Cama, A.; Mariani-Costantini, R. (Siena, Italy)

211 PP165 Different Carcinogenetic Pathways are Activated in Virus Associated and not Associated Primary Hepatocellular Carcinomas Cetta, F.; Montalto, G.; Baldi, C.; De Nisi, A. Raffaelli, N.; Minacci, C.; Zuckermann, M.; Nuzzo, G. (Roma, Italy) 
211 PP166 Impaired Neutrophil Adhesion to Vascular Endothelial Cells in Patients with Obstructive Jaundice

Matsumiya, A.; Yamaguchi, M.; Nakano, H.; Kuzume, M.; Sakai, H.; Machida, H.; Shimura, H.; Matsumoto, T.; Kumada, K. (Yokohama, Japan)

212 PP167 A Study of Hepatocellular Carcinoma Development and Progression in Rat

Onodera, K.; Sakata, H.; Kato, K.; Kasai, S. (Asahikawa, Japan)

212 PP168 Effects of IGF-1 on Post-Hepatectomized Conditions in Normal and Diabetic Rats

Yamaguchi, M.; Matsumiya, A.; Matsumoto, T.; Yoshida, K.; Kuzume, M.; Kumada, K. (Yokohama, Japan)

213 PP169 The Impact of Oral Intake on the Severity of Acute Pancreatitis Şahin, M.; Vatansev, C.; Vatansev, H.; Aksoy, F.; Yilmaz, O. (Konya, Turkey) Hepatobiliary and Pancreatic Surgery III

213 PP170 Liver Hydatid Cyst Cases Rupture into a Bile Duct

Aksoy, F.; Belviranh, M.; Vatansev, C.; Şahin, M.; Er, C. (Konya, Turkey)

214 PP171 Role of Polysorb ${ }^{\circledR}$ Staples in Distal Pancreatic Resection

Farkas, G.; Mikó, I.; Furka, I. (Debrecen, Hungary)

215 PP172 Nitric Oxide Exacerbates the Liver Dysfunction Secondary to Obstructive Jaundice

Wei, T.; Kamiyama, Y.; Satoi, S.; Kitade, H.; Oda, M., Inoue, T.; Zhang, Z.; Okumura, T. (Osaka, Japan)

215 PP173 Improving Effect of Active Hexose Correlated Compound (AHCC) on the Prognosis of Postoperative Hepatocellular Carcinoma Patients

Kaminama, Y.; Matsui, Y.; Kawaguchi, Y.; Morita, H.; Kosuna, K. (Sapporo, Japan)
216 PP174 Selective Thermocoagulation of Unresectable Pancreatic Cancers Using Radiofrequency Capacitive Heating

Kamiyama, Y.; Matsui, Y.; Nakagawa, A.; Nakase, Y. (Osaka and Kyoto, Japan)

216 PP175 Evaluation of the Pressure of Perihepatic Packing

Stanisavlje vic, D.; Gadžijev, E.M.; Wahl, M.; Butinar, J.; Sojar, T.; Trotovsek, B. (Ljubljana, Slovenia)

217 PP176 Reproducible Blunt Liver Injury - A New Experimental Model Wahl, M.; Gadžijev, E.M.; Butinar, J.; Stanisavljevič, D.; Wahl, J. (Ljubljana, Slovenia)

217 PP177 Spiral CT in Differential Diagnostics of Homogeneous Hepatic Lesions

Karmazanovsky, G.; Fedorov, V.D.; Shipuliova, I.V.; Kurochkina, A.I. (Moscow, Russia)

218 PP178 Vascular Complications after Cryosurgery Close to the Vena Cava in the Pig

Jungraithmayr, W.; Szarzynski, M.; Neef, H.; Dogaru, V.; Kirste, G.; Eggstein, S. (Freiburg, Germany)

218 PP179 Total Hepatectomy in the Pig as a Model of Acute Liver Failure

Sosef, M.N.; Abrahamse, S.L.; Chamuleau, R.A.F.M.; von Meyenfeldt, E.M.; van Gulik, T.M. (Amsterdam, Netherlands)

Hepatobiliary and Pancreatic Surgery IV

219 PP180 Pitfalls of Traumatic Bile Duct Injuries in Paediatric Age Group El-Sefi, T.; Marwan, I.; Shawki, A.; El-Ebeidi, G.; Fawzy, A.T.; Abdel-Ghaffar, T.; El-Naggar, O.; Rashed, M.Y.T.; El-Dessouky, M. (Alexandria, Egypt)

219 PP181 Surgical Bypass Versus Endoscopic Stenting for Palliation of Malignant Obstructive Jaundice El-Sefi, T.; Marwan, I.; Rashed, M.Y.T.; Sadek, A.; Helmy, A. (Alexandria, Egypt) 
220 PP182 Fibrin Glue Sandwich to Prevent Pancreatic Fistula following Pancreatectomy

Ohwada, S.; Ogawa, T.; Tanahashi, Y.;

Iwazaki, S.; Satoh, Y.; Takeyoshi, I.;

Kawashima, Y.; Morishita, Y. (Gunma, Japan)

220 PP183 Restrict Diameter of Splenic Vein to Prevent Encephalopathy after Splenorenal Shunt

Dai, X.; Xia, Z.; Ma, K.; Wang, L.; Bu, X.;

Dai, Y.; Yang, F.; Qiu, F. (Shenyang, P.R.China)

221 PP184 Radical Operations for Carcinoma of Papilla of Vater: A New Reconstructional Procedure

Árkossy, P.; Tóth, P.; Kovács, I.; Furka, I.; Sápy, P. (Debrecen, Hungary)

221 PP185 Experience of Surgical Treatment of Patients with Chronic Cephalic Pancreatitis (130 Operations)

Buriev, I.; Danilov, M.; Karapetian, I.;

Karmazanovsky, G.; Guzeeva, E.; Savvina, T.;

Prizov, V. (Moscow, Russia)

Tissue Repair and Wound Healing

222 PP186 Fibrin Glue Antibiotic Incorporated in the Prevention of Prosthetic Graft Infection

Kuriansky, J.; Shabtai, M.; Judich, A.; Keller, N.; Ayalon, A.; Martinovitz, U. (Ramat Gan, Israel)

222 PP187 Development of a Non-Animal Model for Measuring Strength and Adhesion to Vital Human Tissue of Surgical Sealant

Kjaergard, H.K.; Ellensen, V.S.; Pulawska, T.; Larsen, S.S.; Jørgensen, U.; Velada, J.;

Hollingsbee, D. (Copenhagen, Denmark)

223 PP188 Enhanced Migration of Human Keratinocytes Stimulated by Linoleic Acid Methyl Ester of Mole Cricket Species

Zimmer, M.M.; Frank, J.; Hanselmann, R.; Mutschler, W.; Becker, H. (Homburg/Saar, Germany)
223 PP189 Experimental Data on the Urological Applicability of a New Monofilament Synthetic Absorbable Surgical Suture Material, Biosyn/USSC

Mikó, I.; Petö, K.; Kovács, J. Szabó, Gy.; Schmidt, E.; Bráth, E.; Incze, D.; Furka, I. (Debrecen, Hungary)

224 PP190 IGF-I in Rat Skin Wound Healing during Polarized Light Therapy

Micev, M.; Todorović, V.; Nikolić, J.A.; Peško, P.; Simić, A.; Ćosić-Micev, M.; Jekić, I. (Belgrade, Yugoslavia)

225 PP191 Piler Light Therapy-Effect on Wound Healing in Esophagogastric Surgery

Simić, A.; Stojakov, D.; Sabljak, P.; Jekić, I.; Bjelović, M.; Peško, P. (Belgrade, Yugoslavia)

225 PP192 Influence of Sulmycin on the Release of Cytokines from Human Peripheral Leukocytes

Schildhauer, T.; Vogt, P.; Steinau, H.U.; Köller, M.; Muhr, G. (Bochum, Germany)

226 PP193 Experimental Study of a Polylactic Acid Absorbable Pericardial Substitute

Frey, G.; Richard, M.J.; Chaffanjon, P.; Favier, A.; Brichon, P.Y. (Grenoble, France)

227 PP194 Sealing of the Needle Track with Fibrin Glue Following Percutaneous Liver Biopsy in Patients with High Risk for Bleeding

Petsas, T.; Kalogezopoulou, C.P.;

Giannakenos, C.; Kosti, P.; Kazauresini, M.;

Vagianos, C. (Patras, Greece)

Microvascular and Reconstructive Surgery I

227 PP195 Immediate Breast

Reconstruction Following

Subcutaneous Mastectomy

Miura, K. (Niigata City, Japan) 
228 PP196 Microvascular Free Jejunal Graft - Role in Hypopharyngeal Reconstruction

Peško, P.; Bumbaširević, M.; Knežević, J.; Dunjić, M.; Stojakov, D.; Simić, A.; Sabljak, P.; Šaranović, D. (Belgrade, Yugoslavia)

228 PP197 Resection and Reconstruction of Extensive Skull Base Tumors Raveh, J.; Laedrach, K. (Bern, Switzerland)

229 PP198 Modified Lazaro Da Silva Repair for Recurrent Postoperative Hernias

Velitchkov, N.; Losanoff, J.; Kjossev, K.; Michov, R.; Mironov, M.; Losanoff, H. (Sofia, Bulgaria)

229 PP199 Callus Distraction of the Canine-Mandible-Manipulation of the Shape after Linear Distraction

Kunz, Ch.; Büscher, Ph.; Rahn, B.; Hammer, B. (Basel, Switzerland)

230 PP200 Lymph Vessel Derivative and Reconstructive Microsurgery: State of Art

Campisi, C. (Genoa, Italy)

230 PP201 Extensionsplasty by Extensor Indicis Tendon Transposition

Dolderer, J.H.; Kruft, S.; Reill, P. (Frankfurt, Germany)

231 PP202 Tissue Engineered Cartilage after Implantation in an Autologous Rabbit System

Staudenmaier, R.; Klöppel, M.; Naumann, A.; Aigner, J. (Munich, Germany)

Abdominal Sepsis I

231 PP203 Intralipid Based Short Term Total Parenteral Nutrition does not Impair Cellular Immune Reactivity in Rats

Gross, T.; Babst, R.; Juretic, A.; Herzog, B.;

Gudat, F.; Heberer, M.; (Bonn, Germany)
232 PP204 Anti-TNF-Antibody does not Influence Survival in a Model of Pneumoccocal Sepsis in Pigs

Gawad, K.A.; Schneider, C.; Hufländer, A.; Mack, D.; Izbicki, J.R. (Hamburg, Germany)

232 PP205 Kupffer Cell Function in Intraabdominal Infection

Emmanuilidis, K.; Fleischmann, T.; Zantl, N.; Maier, S.;, ven Rooijen, N.; Holzmann, B.;

Heidecke, C.D. (Munich, Germany)

233 PP206 Immunmodulation with Interferon- $\gamma$ in Acute Pancreatitis

Schuster, K.L.; Richter, A.; Bertsch, Th.; Wendl, K.; Schlüter, M.; Klaebisch, G.; Post, S. (Heidelberg, Germany)

Late Abstracts

Oral Presentations

Miscellaneous

234202 Fibrin Glue as an Antiadhesive Agent in a Rabbit Model

Buxbaum, P.; Simunek, M.; Rokitansky, A.M.; Redl H. (Vienna, Austria)

234203 Expression of Thymidine Phosphorylase in Carcinoma of the Papilla of Vater is Closely Related with Tumor Progression and a Poorer Prognosis

Zhao, B.; Kimura, W.; Futakawa, N.;

Makuuchi, M.; Muto, T. (Tokyo, Japan)

235 Author Index

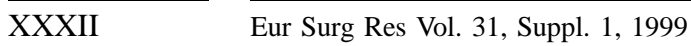

34th Congress of the European Society for Surgical Research 